pt.1-3

Suringar, W. F. R. (Willem Frederik Reinier)

Botanische excursie naar Nederlandsch West_Indië

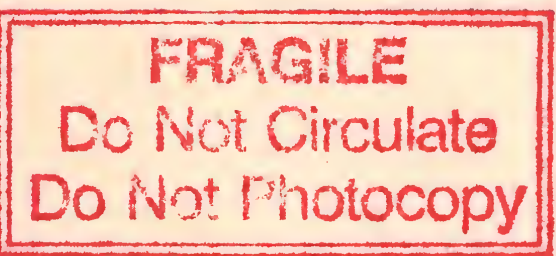





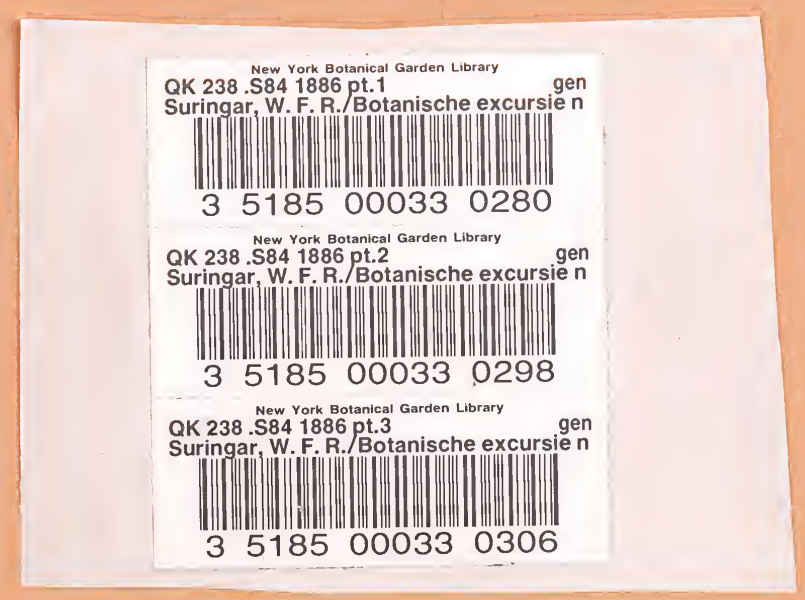

Hollinger Corp.

pH 8.5 


$$
\text { v.d. }
$$

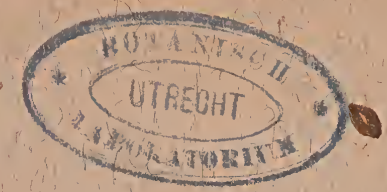

Jurngar Reisvertial

I. 




\title{
BOTANISCHE EXCURSIE
}

\author{
NAAR
}

\section{NEDERLANDSCH WEST-INDIË.}

\section{REISVERHAAL}

door Dr. W. F. R. Suringar te Leiden.

\section{Heenreis. Sargasso-zee. Aankomst te Paramaribo.}

Den I 2 den. December I884, des morgens te Io uur, vertrokken wij per Prins Maurits, kapitein Sluiter, uit Amsterdam.

Gelijk reeds uit de mededeelingen omtrent het plan der expeditie in haar geheel (Tijdschrift van het Aardrijkskundig Genootschap, 2de Serie Dl. I, p. $3^{\text {I } 5}$ en 639) bekend is, bestond het gezelschap, behalve schrijver dezes, uit Dr. K. Martin, hoogleeraar in de geologie te Leiden, en drie jongelieden, die, of wier betrekkingen voor hen, verzocht hadden de wetenschappelijke reis te mogen medemaken: nl. den heer G. A. F. Molengraaff, doctorandus in de natuurhistorische vakken en geologie, den heer J. R. H. Neervoort van de Poll, entomoloog, en den heer J. van Breda de Haan, aankomend student in de botanie.

Verwanten, vrienden, bekenden, vergezelden ons tot aan boord, onder hen de President en Secretaris van het Aardrijkskundig Genootschap, welks bestuur den eersten aanstoot tot de expeditie had gegeven, de heer G. A. B. Hellmund, die ons door zijne relatien met Curaçao, in de voorbereiding van onze plannen in menig opzicht had bijgestaan, en de bejaarde maar steeds wakkere bestuurder van "Natura Artis Magistra", de heer Westerman, wien het ons goed deed, nog eens vóbr het vertrek de hand te drukken, wel wetende, hoezeer elke poging, om de wetenschappelijke eer en belangen van Nederland ook daarbuiten en in zijne koloniën te behartigen, zijne warme sympathie ondervindt.

Het was koud en guur. Langzaam ging het door het kanaal naar IJmuiden.

Hoe zullen de onzen het maken gedurende onze afwezigheid? Zullen 
wij zelven in gezondheid tot hen wederkeeren? Zullen onze pogingen met een uitslag bekroond worden, die tegen de bezwaren van de afwezigheid en van de reis opweegt? Die vragen gingen natuurlijk in ons om, terwijl wij langzaam heengleden door de Hollandsche duinstreek, de sluizen verlieten en onze blikken nog wendden naar de vaderlandsche kust.

Echter, buitengaats gekomen, begint het schip vrij wel te slingeren en te stampen. Men moet zorgen op de been te blijven; de gure wind doet naar een warm plaatsje zoeken; en zoo geven de lichamelijke gewaarwordingen een andere wending aan den gedachtenloop. De kring van deze wordt beperkt. Hij bepaalt zich, zoo niet tot het eigen ik, tot de naaste omgeving, tot het schip, 250 voet lang en eenige meters breed, onze aangewezen woonplaats voor de eerste vier weken, tot zijn bevolking, ruim vijftig man in het geheel, tot de medepassagiers in de kajuit, vijf personen en drie kinderen. Ook met deze is de kennismaking nog zeer vluchtig. Aan tafel komen maar drie personen op de hun voor de reis aangewezen plaatsen, ver uiteen; de overigen zijn in hun kooien of hier en daar op het dek; en 't meeste wat men hoort, is het eentoonig trio van zee, wind en stoommachine.

Den volgenden dag, na geslapen te hebben, en de ruimte in hut en kooi niet z 66 bekrompen te hebben gevonden als zij ons anvankelijk toescheen, begint ieder zich beter thuis te gevoelen. Wij bewonderen de wakkere predikantsvrouw, die, zelve nog niet aan den wankelen bodem gewend, man en kinderen onvermoeid met raad en daad bijstaat; wij leeren een tweetal zeeofficieren kennen, even als het genoemde gezin bestemd voor Suriname, wier humor en onuitputtelijke voorraad van anecdoten ons later menig gezellig uur in de rookkamer zullen verschaffen; met hen een jongmensch, die zich voorstelt op een plantage in dezelfde kolonie de belangen des bezitters in Nederland te helpen behartigen. Wij beginnen den dokter op zijn hygiènisch heen en weer stappen op de kampanje te vergezellen; wij zien naar de wijzers der log, door de schroef zonder eind, die ver achter het schip in haar kokertje wordt medegesleept, in draaiing gebracht, en hooren naar de tikken, die (voor het oogenblik nog langzaam genoeg) telkens den vooruitgang van een engelsche mijl verkondigen. Wij bezoeken den kapitein, wiens beschaafd en vriendelijk gezelschap wij hoe langer hoe meer zullen waardeeren, op de brug, waar hij thans nog onverpoosd de wacht houdt; wij krijgen van hem vergunning om de schatten der kaartenkamer te raadplegen, iets waarvan wij herhaaldelijk een erkentelijk gebruik hebben gemaakt. 
Ook het wetenschappelijk bewustzijn ontwaakt weder. In de talrijke meeuwen, die ons vergezellen, en die ons met steeds verminderend aantal, tot den $22^{\text {sten }}$ op ongeveer $30^{\circ}$ N.B. zullen gezelschap houden, worden door den heer Martin, van ouds liefhebber van vogelstudiën, twee soorten, Larus canus en Larus ridibundus herkend.

De Engelsche kust naderende, wordt een $W$ ea $1 \mathrm{~d}$ e $n$-formatie aangewezen, hetgeen de herinnering opwekt aan de groote kruipende dieren (Iguanodon), die hier in voorwereldlijke tijden leefden, en op wier graf thans vreedzame koeien en schapen grazen; elders wekken de krijtrotsen met hare regelmatige lagen van vuursteenknollen, opgebouwd door microscopische organismen, rechtmatige bewondering.

Te Brighton wordt onze goede reis tot dusverre naar den wal geseind.

Snel ging het in den beginne niet. Altijd hadden wij een sterken Zuidwesten-wind tegen, die ten slotte het schip zoodanig deed stampen, dat de schroef telkens boven water kwam en slechts met halve kracht gewerkt kon worden. Vele schepen zagen wij „bijleggen”. Langzaam voortstoomend kwamen wij eerst in den avond van den $55^{\text {den }}$ op de grens van het onderzeesch plateau, dat Engeland aan het vaste land van Europa verbindt en vanwaar de zeebodem plotseling steil, van weinige honderden meters, tot de, bij kilometers te tellen, diepte van den oceaan afdaalt. Tot afscheid kregen wij nog een zee, die in de kajuit de deuren der hutten deed openslaan, de leuningen der banken overwierp, koffers en doozen in de hutten door elkander deed rollen, en in de rookkamer op het dek de personen van de banken, met de papieren, boeken, glazen enz. van de tafel, in grenzenlooze verwarring door elkander mengde. Echter waren de meesten nu reeds zoover aan het woelig element gewoon geraakt, dat dit zijn eenigszins krachtig optreden meer vrolijkheid dan werkelijken last veroorzaakte.

De Atlantische oceaan ontving ons wel is waar met regen, maar met een zachter temperatuur ( $6 \mathrm{I}^{\circ} \mathrm{F}$.) dan wij tot dusver hadden gehad; den volgenden rag was het helder, na een prachtigen zonsopgang; en nog een dag later, dus den I8den, op $40^{\circ}$ N.B. gekomen, vonden wij de winterkoude, waarin wij uitgegaan waren, vervangen door een heerlijke voorjaarslucht van $64^{\circ}$, met vrolijken zonneschijn op de thans breede vlakke golven. De patrijspoorten werden opengezet, en, met de frissche atmospheer in salon en hutten, stroomde ook nieuwe levenslust in ieders borst.

De lucht was reeds nu zoo helder geworden, dat des avonds o. a. het licht van Sirius duidelijk in de zee weerkaatst werd. Van nu af werden in menig rustig avonduur de blikken naar den sterrenhemel gewend. 
Terwijl wij langzamerhand de poolster met den grooten beer zagen zakken, werd verlangend uitgezien naar hetgeen aan de andere zijde uit den horizon zou oprijzen. Op de kaart, die dokter Gaill bezat, en die hij ons gaarne liet raadplegen, zochten wij de plaats van het zuider kruis, maar in dit seizoen kwam het te laat op, om het in de werkelijkheid aan den hemel te kunnen waarnemen. Later, op de eilanden en in Venezuela, zouden wij dit kleine maar nette sterrebeeld zien, en den tropischen sterrenhemel in zijn volle pracht te aanschouwen krijgen.

Vergoeding gaf thans de maan, wier helder sikkeltje, reeds meer hellend dan op onze breedte, weldra in den namiddag zichtbaar werd, en die ons in steeds toenemenden glans tot Paramaribo vergezelde.

Menigen avond, als wij in onze luierstoelen langs het boord gezeten, in de zoele lucht als van een Venetiaanschen nacht, haar schitteren en dansen zagen in het zacht golvend en rimpelig zeevlak, beklaagden wij de onzen, die thans in Holland vermoedelijk in mist of sneeuw de grauwe winterdagen beleefden.

Van de lente kwamen wij weldra in den zomer.

In de buurt der Azoren, die wij in den nacht van 19 en 20 December passeerden, hadden wij nog een echt Hollandsche betrokken lucht met zoelen regen $\left(63^{\circ}\right)$. Twee dagen later was het bij de $70^{\circ}$ en nog vier dagen later $78^{\circ}$, terwijl wij inmiddels op den $24^{\text {sten }}$ den kreeftkeerkring hadden gepasseerd. De regens, die in dezen tijd vielen, bij Oost en Zuid-Oostenwind, waren dikke plasregens, afgewisseld door aangenamen zonneschijn, en in den nacht een weinig weerlichten in de verte. Jammer genoeg misten wij een natuurverschijnsel, dat wij gaarne hadden gezien, nl. het St.-Elmsvuur. Wij werden er voor gewekt, maar toen wij, na in der haast een paar kleeren te hebben aangeschoten, naar boven kwamen, woei ons een koude regen in het gezicht en was er zoo goed als niets meer te zien. Wij konden ons dus alleen een voorstelling maken naar de beschrijving, en, in onze kooi teruggekeerd, in halven droom, het electrisch licht op de toppen van ra's en masten zien uitstroomen als de lichtjes van een reusachtigen kerstboom (het was juist de nacht tusschen 24 en 25 December), maar bij dien droom moest het ditmaal blijven.

Toen wij ontwaakten, en ons aan de ontbijttafel vereenigden, vonden wij voor het eerst de stormlatten van de tafel; met een fraaien regenboog namen de buien afscheid, en den volgenden dag hadden wij een zeer stille zee, slechts klein gerimpeld en hier en daar met zoogenoemde katte. pooten (scherp begrensde, geheel effen vlakten, waar volkomen windstilte is). Wij waren op $17^{\circ}$ N.B. en onder den invloed van den passaat ge- 
arriveerd. De lucht vertoonde de eigenaardige cirrhocumuli, kieine, tot aan den horizon zich scherp begrensd toonende wolkjes, die langzamerhand in de, door de nabijheid grooter schijnende, geisoleerde wolken boven ons overgaan. De zon scheen helder. Wij hadden $80^{\circ}$, en waardeerden de zonnetent, die sedert den dag, waarop wij den keerkring passeerden, was aangebracht; van een bezoek aan het bagageruim en onze koffers maakten wij gebruik, om de voor de tropen bestemde kleederen voor den dag te halen, en zoo werden wij als het ware in het nieuwe klimaat ingewijd.

Van nu af steeg de middagtemperatuur tot $85^{\circ}$, om welke hoogte zij bleef heen en weer gaan, ook later op de route van Suriname naar Curaçao, die, gelijk men weet, juist in den warmte-aequator gelegen is.

De dagen, die ons nu nog restten vóór Paramaribo, waren dagen van ongestoord gevoel van welbehagen. De heldere zon overdag, de steeds voller wordende maan bij avond, heldere zons- op en ondergangen, de frissche zeewind, alles was opwekkend. De ruimte op de boot was niet groot, maar ook het gezelschap was klein, daarbij gezellig en aangenaam.

Onder de tent zat men genoegelijk bijeen. De rookkamer was reeds lang onze bibliotheek. De „Admiralty Manual of Scientific Enquiry”, Neumayer's "Anleitung zu wissenschaftlichen Beobachtungen auf Reisen," Kappler's „Hollăndisch-Guiana, Erlebnisse und Erfahrungen wăhrend eines 43jăhrigen Aufenthalts in der kolonie Suriname”, Teenstra ,de Nederlandsche West-Indische eilanden," Amsterdam 1836, Simons „beschrijving van het eiland Curaçao", Bisschop Grevelink's verhandelingen over St. Eustatius, uit de „Bijdragen tot de kennis der Nederlandsche en vreemde koloniën I 846 en $\mathbf{1} 847$, hadden wij daar, met verschillende kaarten, liggen, zoodat ieder, naarmate hij lust gevoelde, zich eenigermate op het terrein, dat wij zouden gaan bezoeken, kon orienteeren.

Grage lezers vond ook Kingsley's „At last, a christmas in the West Indies", dat mij vóór de reis door een mijner vrienden was aanbevolen, en een zeer boeiende beschrijuing van een bezoek aan Trinidad, gedurende drie wintermaanden, behelst. Even als bij hem, stond ook voor schrijver dezes een reeds lang gekoesterde wensch, om de tropenwereld met eigen oogen te aanschouwen, vervuld te worden. Even als hij, hoopten wij door onze reis te toonen, cat aan een bezoek der West-Indien niet zooveel bezwaren verbonden zijn als men veelal gelooft; de reis had plaats in hetzelfde saisoen, en zoo waren er vele punten van aanraking.

De schetsen van Kappler over Suriname geven een zeer onderhoudend beeld van het land, en van een werkzaam worstelen van een kolonist tegen vele zwarigheden. De aangehaalde werkjes over de Nederlandsch 
West-Indische eilanden geven het een en ander omtrent ligging, klimaat, natuurlijke historie, statistiek en geschiedenis, dat tot voorloopige oriënteering dienst kan doen, en ons ook gedaan heeft.

Wat de kaarten betreft, zoo was natuurlijk in de eerste plaats de groote kaart van Suriname, naar de opmetingen gedaan in de jaren $1860-$ I879 door J. F. A. Cateau van Rosevelt en J. F. A. E. van Lansberge, door den Heer Martin, ten behoeve van zijn voorgenomen reis langs de Suriname-rivier, na afloop van het onderzoek te Curaçao, Aruba en Bonaire, medegenomen. Van Curaçao hadden wij de groote kaart, in 1836 door de Wed. G. Hulst van Keulen te Amsterdam uitgegeven, en de nieuwste, op kleinere schaal, van den Heer Kuyper, door het Aardrijkskundig Genootschap, in deel VI. I882 van zijne werken, gepubliceerd. Voor Bonaire, de kaart in 1867 gedrukt, bij gelegenheid van den verkoop der gronden aan dat eiland van gouvernementswege op I September I868, I) voor Aruba die van den kapitein R. F. van Raders, gepubliceerd met de verhandeling van Reinwardt over de gesteldheid van den grond van dat eiland en het aldaar gevonden goud (Verh. Kon. Ned. Instituut, deel I. I827) 2). Het bleek later, op Aruba zelf, dat ook nog een kaart daarvan gepubliceerd is door de Aruba Island Gold Mining-Company (zie bericht van den Heer Martin hierover in zijn reisverhaal, tijdschrift van het Aardrijkskundig Genootschap, 2, II. p. 350). Voor St. Eustatius bezaten wij de kaart, volgens de opname van A. H. Bisschop Grevelink, in het Tijdschrift van het Aardrijkskundig Genootschap, deel I, gepubliceerd, met bijschrift van den Heer A. R. B. Blommendaal; voor St. Martin die van Dr. J. Dornseiffen, in deel VII van hetzelfde tijdschrift $188_{3}$, met eene uitvoerige verhandeling, betreffende de cartographie, geschiedenis, beschrijving en statistiek van het eiland, opgenomen. Van Saba hadden wijgeen kaart kunnen krijgen en scheen er geen in Nederland bekend te zijn. Het bleek ons echter later op de reis, dat er een gedrukt en uitgegeven is op St. Thomas, ontworpen door een vroegeren gezaghebber van Saba, den heer M. L. Statius van Eps. De heer Molengraaff, die, na op Curaçao Aruba en Bonaire aan de herborisaties te hebben deelgenomen, naar de bovenwindsche eilanden vertrok om de geologie van deze te bestudeeren,

I) Het eiland Bonaire (met schetskaart). Omschrijving der kavels en voorwaarden van verkoop van het meerendeel der domeingronden en zoutpannen aldaar op I September I868, benevens van eenige perceelen binnen dien termijn en op nader te bepalen tijd. 's Hage, Gebr. Belinfante $\mathbf{1} 867$.

2) Waarnemingen aangaande de geschiktheid van den grond van het eiland Aruba en het goud aldaar gevonden door C. G. C. Reinwardt, 1827. 
deed op den weg daarheen St. Thomas aan, en kon daar nog een exemplaar van genoemde kaart verkrijgen, op welke later, naar aanleiding van een geteekende kaart, bij den heer Jonckheer op Saba aanwezig, en de aanwijzingen van dezen, nog eenige verbeteringen konden worden aangebracht.

Voeg bij het bovengenoemde eenige overzichtskaarten, bij de boeken nog een paar zoölogische en botanische werken, en aanteekeningen uit andere, waarvan ter zijner plaatse gewag zal worden gemaakt, en gij hebt eene voorstelling van onze reisbibliotheek, die uit den aard zeer beknopt moest zijn.

Uit de zeer uitgebreide litteratuur over Suriname, (o. a. behandeld in het artikel van de HH. C. M. Kan en P. J. Veth, in de Catalogus der Afdeeling "Nederlandsche Koloniën" van de Internationale Koloniale en Uitvoerhandel-tentoonstelling $\mathrm{I}_{8} 88_{3}$ te Amsterdam, Brill, Leiden $\mathrm{I} 883$ p. 20,2 I) hadden wij dus slechts een enkel werk, dat zich het naast bij onze plannen aansloot, medegenomen, en uit de litteratuur over de eilanden I) datgene gekozen, wat ons, na voorafgaande lectuur, het meest bruikbaar was gebleken.

Terwijl dus deze litterarische apparaat nu en dan geconsulteerd werd, ook bij nadere besprekingen van het reisplan, was er één tijd var den dag, waarop men ons, gedurende de geheele reis, geregeld in de rookkamer bijeen kon vinden, nl. te $\mathbf{2} 2$ uur. Wij waren dan in afwachting van het bestek, dat daar elken dag werd opgehangen, met vermelding van de Lengte en Breedte op den middag, den koers, het aantal in het laatste etmaal gemaakte Duitsche mijlen, en het nog overblijvend aantal mijlen tot Paramaribo. De eerste dagen, in het kanaal, hadden wij maar $38,43,34$ en 5 r D. M. gemaakt, later was het minste $55^{3 / 4}$, het meeste 65 , gewoonlijk iets over de 60 , terwijl de geheele afstand ro6o D. M. bedraagt. Hoezeer het ous aan boord beviel, zoo ging er toch telkens een gejuich op, wanneer de aangekondigde „verheid“ het gemiddeld aantal mijlen overtrof, vooral wanneer den vorigen of de vorige dagen de zon niet geschenen had en dus de laatste bestekken "gegiste"

I) Behalve de bovengenoemde: Beschrijving van Curaçao en onderhoorige eilanden door een inwoner van dat eiland (I8I9); G. van Lennep Coster, Aanteekeningen gehouden gedurende mijn verblijf in de West-Indiën in $1837-1840$; G. C. Bosch, Reizen in de West-Indiën en door een gedeelte van Z. en N. Amerika I829-I843; Teenstra, Beknopte beschrijving van de Nederlandsche overzeesche bezittingen $185^{2}$; S. van Dissel, Curaçao, herinneringen en schetsen 1857; J. H. Hering, Beschrijving van het eiland Curaçao en de daaronder behoorende eilanden I879; A. M. Chumaceiro, de natuurlijke hulpbronnen van de koḷnie Curaçao r88o, 
waren geweest, nl. opgemaakt uit den koers en de aanwijzing van de log.

Lt. Sachse had de goedheid, het bestek telkens op een mijner kaarten uit te passen en aan te teekenen, waardoor wij de afgelegde route altijd zichtbaar voor ons hadden.

Tegelijkertijd met het bestek had de eerste stuurman de vriendelijkheid, ons de waarnemingen van barometerstand en temperatuur mede te deelen. Daar de kapitein van goede instrumenten, van het Meteorologisch instituut, voorzien was, en meermalen een premie, wegens de beste meteorologische obervaties op zijn reizen, had behaald, leverde dit eene geschikte gelegenheid op, om de door ons medegencmen instrumenten te vergelijken. Het Meteorologisch instituut had ons eenige thermometers en een paar kleine anerorden geleend. De Heer Martin had zelf een grooter aneroyde, bestemd voor de bepaling van niveauverschillen bij het geologisch onderzoek, medegenomen. Van de kleinere instrumenten voldeed een kleine aneroide, mij door mijn zwager Dr. C. G. van Mansvelt geleend, in die mate, dat hij later aan den Heer Molengraaff, bij diens geologisch onderzoek van de bovenwindsche eilanden, goede diensten bewijzen kon. In 't algemeen zijn de hoogten, die ook voor de geografische verspreiding der planten van belang zijn, op de kaarten der eilanden niet juist en doorgaans te groot aangegeven. Wanneer ik later, bij de beschrijving van den plantengroei, van hoogten melding zal maken, zullen het dus altijd de hoogten zijn, die door de Heeren Martin en Molengraaff op deze reis zijn bepaald.

Schepen zagen wij op het geheele traject door den oceaan ter nauwernood een paar. Des te meer trof de ontmoeting, op den laatsten dag v66r Paramaribo, van Prins Willem I, van dezelfde Maatschappij, op weg naar Nederland. De booten kwamen dicht genoeg bij elkander, voor de passagiers van beide om elkander toe te wuiven, voor de kapiteins om door den scheepsroeper eenige woorden te wisselen. Dan drie stooten met de stoomfluit tot afscheid, de schepen verwijderen zich elk zijns weegs, Prins Willem I duikt achter de kimmen, en binnen een half uur zien wij niets meer dan het eenzaam watervlak.

Dit maakt overigens niet den indruk van die oneindige uitgestrektheid, als aan onze stranden, waar de aan den horizon benevelde lucht de grenzen doet vervloeien. De scherpe grenzen, waarbij b.v. kleine wolkjes aan den horizon duidelijk door dezen door midden worden gesneden, verkorten den afstand. Wanneer de lucht naar alle zijden helder was, vertoonde de zee zich aan ons oog als een vrij beperkten, scherp geteekenden cirkel; was de lucht aan de ééne zijde helder, aan de andere 
eenigzins nevelachtig, dan viel het onderscheid met buitengewone duidelijkheid in het oog.

Overigens leert men op zulk een zeereis begrijpen, dat er schilders zijn, die de zee met haren rijkdom van vormen en tinten tot onderwerp van hunne voortdurende studie hebben gekozen. $\mathrm{Nu}$ eens de boeg vangend in een donzig bed van sneeuwwit schuim, waaruit men zonder verwondering op nieuw de godin der schoonheid zou zien geboren worden, dan weer zwart met breede, gladde golven, er hard uitziende, gelijk Kingsley niet oneigenaardig opmerkt, als een vaste massa van obsidiaan; $\mathrm{nu}$ eens effen of flauw gerimpeld, een andermaal hevig bewogen, niet zelden met gekruiste deining en zee, in verschillende verhouding van kracht, naarmate van den wind, die voorafgegaan is, en van dien, welke op het oogenblik heerscht; daarin de reflectie van lucht en wolken, helder blauw en wit, naar den avond met roode en die fijne groene tinten afgewisseld, die zoo dikwijls een sieraad zijn van de tropische avondlucht; en die reflecties wisselend met het spel der golven en rimpels, en in tallooze schakeeringen dooreengemengd. Zij levert een schouwspel op, waarnaar men telkens terugkeert, en dat men niet moede wordt te volgen en zooveel mogelijk te ontleden.

$\mathrm{Nu}$ en dan wordt het tooneel verrijkt door dierlijk leven in de lucht of op of in het water. Ik maakte reeds melding van de zeemeeuwen, die ons bij afwisseling en met steeds verminderd aantal, tot op ongeveer $30^{\circ} \mathrm{N}$.Br. gezelschap hielden. Bij het verlaten van het kanaal werd hun gezelschap voor een dag verrijkt door eenige duikeenden (waarschijnlijk Mergus), bij den wintertijd uit het hooge Noorden afgezakt, en die ons op proeven van hunne behendigheid onthaalden; later, bij onze nadering tot de Azoren en op de hoogte daarvan, met een aantal stormvogeltjes of $\mathrm{M}$ a la vista (Procellaria pelagica).

Ook zwommen in die buurt een aantal groote zeeschildpadden om het schip. Voorts zagen wij nu en dan, bij stille zee, een exemplaar van de sierlijke kwal (Physalia), zuideliiker ook de blauwe Velella, met als een zeiltje opgezette kam, het zoogenoemd „Portugeesch oorlogschip”. De namen „bazaantje' en ,,voor den wind zeiler”, door van der Hoeven genoemd, waren bij onze zeelieden niet bekend.

Des avonds gaven over de geheele reis, nu en dan, de kleine Noctiluca's en grootere kwallen aanleiding tot het bekende lichten der zee. Over dag waren het de „Boer met zijn varkens” die, van het verlaten van het kanaal af tot dicht bij Suriname toe, doch met tusschenpoozen van afwezigheid, ons in groepen met hun dartele sprongen vermakten. Zij ga- 
ven nog tot eene discussie over nomenclatuur aanleiding, doordien wij ze, in aansluiting met den wetenschappelijken naam, Delphinus delphis, en, met de oude klassieken, dolfijnen noemden, terwijl de zeelieden onder dolfijn geheel iets anders, nl. een vischsoort: Dol phij $\mathrm{nvisch}$, Coryphaena, verstaan.

Evenzoo rees een vraag omtrent de grootere walvisschen (P otvis ch, Noordkapers, Physeter macrocephahus), die wij in de tweede helft der zeereis een paar malen hun fonteinen uit de zee zagen opspuiten.

De vroegere volksmeening, dat dit water was, met prooi van zeedieren in den bek opgenomen en door de neusgaten verwijderd, is lang weersproken. Zie o. a. van der Hoeven, Zoöl. II, p. 659, waar de verschillende litteratuur wordt aangehaald. Meer waarschijnlijk werd toen geacht, dat het slechts een dampzuil zou zijn, door de neusgaten uitgeblazen, en die zich, door de hoogere warmte der walvisschen, vooral in de koudere streken, duidelijk in de omringende lucht afteekent. Hoe is dit nu echter in de warme streken, als deze, op $38^{\circ}$, en vooral lager nog, op $8^{\circ} \mathrm{N}$.Br., bij een luchttemperatuur van $84^{\circ} \mathrm{F}$., die geen ademtocht zichtbaar maakt, en waar wij toch de neusfonteinen duidelijk zagen springen?

De dieren waren te ver verwijderd, om te zien, of zij wellicht de neusgaten bij het uitademen nog even onder water hadden, en dus het bovenliggend zeewater opbliezen, dan of de zaak op eene andere wijze moet worden verklaard. Maar dat het water was, dat zich naar boven in een stuivende wolk van droppels verdeelde, scheen in geen geval twijfelachtig.

$\mathrm{Na}$ onze tehuiskomst werd mij de zaak opgehelderd door mijn vriend dr. P. P. C. Hoek, die mij opmerkzaam maakte op een in $188_{3}$, in verband met de Internationale visscherijtentoonstelling, uitgegeven werkje van Henry Lee: „Seefables explained".

Men vindt daar de geheele geschiedenis onder het hoofdstuk ,the spouting of whales" p. 6I-75 behandeld.

Een paar afbeeldingen, uit een werk van Olaus Magnus van de I6de eeuw ontleend, illustreeren de overdreven voorstellingen, die men zich destijds maakte. Schepen zelfs dreigen onder de massa ingespoten water te vergaan. Ook een andere afbeelding, aan een recent werk ontleend, wijst de fout aan, die velen tot voor korten tijd begingen, door zich dikke in een boog weder nedervallende waterstralen voor te stellen.

Bij den echten Noordschen walvisch liggen de neusgaten (ook spuitgaten genoemd) boven op den kop, zoodat hij zijn bek geheel onder water kan houden, terwijl hij met het boven wạter liggend deel uit- en 
inademt en dan natuurlijk alleen damp ontwikkelt. De spuitgaten zelve zijn, als het dier geheel onder water duikt, gesloten door een huidplooi, die als een konische stop in de opening past; bovendien zijn mond- en neusholte door een stevige sluitspier gescheiden.

Wanneer de adem uitgestooten wordt, terwijl het spuitgat zich nog even onder water bevindt, wordt een kolom zeewater mede opgeblazen. Bij den Physeter geschiedt dit des te eerder, omdat daar de neusgaten meer naar voren op den snoet samenkomen. Deze blaast ook slechts één fontein, vaak eenigszins schuins naar voren. Juist zoo hadden wij het ook gezien.

De inademing heeft natuurlijk altijd met de neusgaten boven water plaats, en duurt bij den Physeter maar ééne seconde. De uitademing duurt drie seconden. Het dier kan, zonder adem te halen, een uur à vijf kwartier onder water blijven.

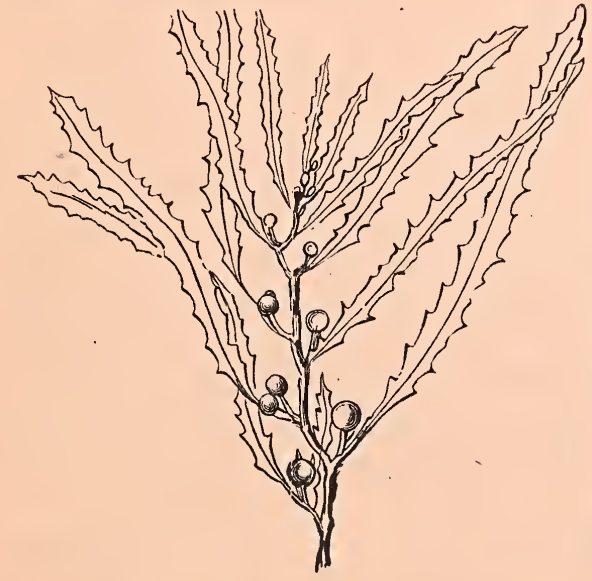

De eenige vertegenwoordiger van het plantenrijk, dien wij op dezen overtocht ontmoetten, was het bekende $\mathrm{S}$ a r g a s s o of druifwier (Sargassum bacciferum).

Algemeen is men het er thans over eens, dat dit zeewier niet in de volle zee groeit, noch in de diepte van den zeebodem banken vormt, maar van den rotsigen zeebodem langs de kust wordt losgerukt, om in zee rond

te drijven, totdat het vergaat en onderzinkt.

Maar zoowel over de uitgebreidheid van het gebied, waar het ronddrijft, de zoogenaamde Sargasso-zee, als over de plaats, waar het oorspronkelijk groeit, loopen de opgaven en meeningen uiteen.

Zoo wordt o. a. in de genoemde Admiralty Manual, van 187 I (ten naasten bij in aansluiting met Rennell en deze met de zoogenoemde groote Fucusbank van Humboldt) een areaal aangegeven, dat zich als een smalle strook van het noorden naar het zuiden (op $40^{\circ} \mathrm{L}$. tusschen den 3 osten en 4 osten breedtegraad) uitstrekt, terwijl Neumayer (1875) 
een van oost naar west gericht, ongeveer elliptisch gebied aanteekent, tusschen $30^{\circ}$ en $70^{\circ} \mathrm{L}$. en $17^{\circ}$ en $37^{\circ} \mathrm{N} . \mathrm{Br}$.

Dr. Otto Kuntze heeft (Engler's Jahrb. I. ז880) de verschillende opgaven omtrent de grenzen van de Sargasso-zee, benevens een aantal punten, waar het ,wier" door verschillende reizigers wel of niet werd waargenomen, in kaart voorgesteld, waardoor een duidelijk overzicht van de verschillende voorstellingen hieromtrent verkregen wordt.

Het spreekt van zelf, dat van een scherpe grens van het Sargassogebied geenerlei sprake kan zijn. Het is een beweegelijke massa, die zich door den wind verplaatst, verdeelt of samenvoegt. Hetgeen men dus kan geven, is een omtrek, waarbinnen de meeste waarnemingen van eenigszins belangrijke hoeveelheden Sargassum vallen: en, naar hetgeen ik daaromtrent uit verschillende bronnen heb aangeteekend, en zeIf op de reis waargenomen, komt het mij voor, dat de door Neumayer gegeven omtrek vrij wel aan dit vereischte voldoet, behoudens aanvulling van de ellips aan de zuidwestzijde (waar zij bij hem een inham vertoont) zoodat zij de reeks der Antillen op de hoogte van St. Thomas doorsnijdt.

Voor die plaats wordt het voorkomen van Sargassum door Wild opgegeven (zie Kuntze 1. c. p. 233) en ook op ons traject van Curaçao naar de eilanden boven den wind, kwam een vrij groote hoeveelheid Sargassum in rijen op die hoogte (5 April $18 \mathrm{l}_{1}^{\circ}{ }^{\circ}$ N.B., $54^{\circ}$ L.) voor; desgelijks was het overvloedig bij St. Martin $\left(18^{\circ}\right.$ N.B., $63^{\circ}$ L.) tijdens onze aankomst aldaar ( $3^{\circ} \mathrm{April}$ ) en gedurende de volgende dagen van ons verblijf.

Binnen deze ellips vallen dan ook onze waarnemingen op het traject van St. Kitts naar New-York, den $24^{\text {sten }}$ Mei: Sargassum in rijen, den $25^{\text {sten }}$ : weinig, den 26 sten : veel, ook in velden, den $27^{\text {sten }}$ desgelijks. Wij bewogen ons gedurende die dagen ongeveer van $2 \mathrm{x}^{\circ}$ N.B. en $64^{\circ} \mathrm{L}$. naar $3 \mathrm{r}^{\circ}$ N.B, en 69 L.

Op onze heenreis van Amsterdam naar Suriname werd Sargassum gezien op 23 Dec. $\left(26^{1 / 2^{\circ}}\right.$ N. B. $36^{\circ}$ L.): weinig; 24 Dec. $\left(23^{\circ} 1 / 2\right.$ N.B. $39^{\circ}$ L. $)$ : vrij veel, ook in rijen; op 25 Dec. $\left(2 \mathrm{O}^{1} / 2^{\circ}\right.$ N.B. $4 \mathrm{I}^{1 / 2}{ }^{\circ} \mathrm{L}$.) : weinig. $\mathrm{Na}$ vele vergeefsche pogingen, wegens de snelle vaart van het schip, gelukte het eindelijk aan den heer van Breda de Haan, om, met een geimproviseerden harpoen, een voorwerp aan te haken en op te halen. Volgens de mededeeling van den kapitein was er minder dan gewoonlijk, en begon het ook op lager breedte dan hij het op andere reizen had waargenomen. Op $2 \mathrm{I}$ Dec., toen het middagbestek $321 / 2^{\circ}$ N.B. en $29^{1 / 4^{\circ}} \mathrm{L}$. aanwees, hadden wij, volgens zijne vroegere ondervinding, reeds Sargassum kunnen zien. 
Tijdschrift r. h. NEDERL: AARDRIWKSKUNDIC CENOUTSCHAP. Jaargang 1886.

Kaart $N^{\circ} 2$.

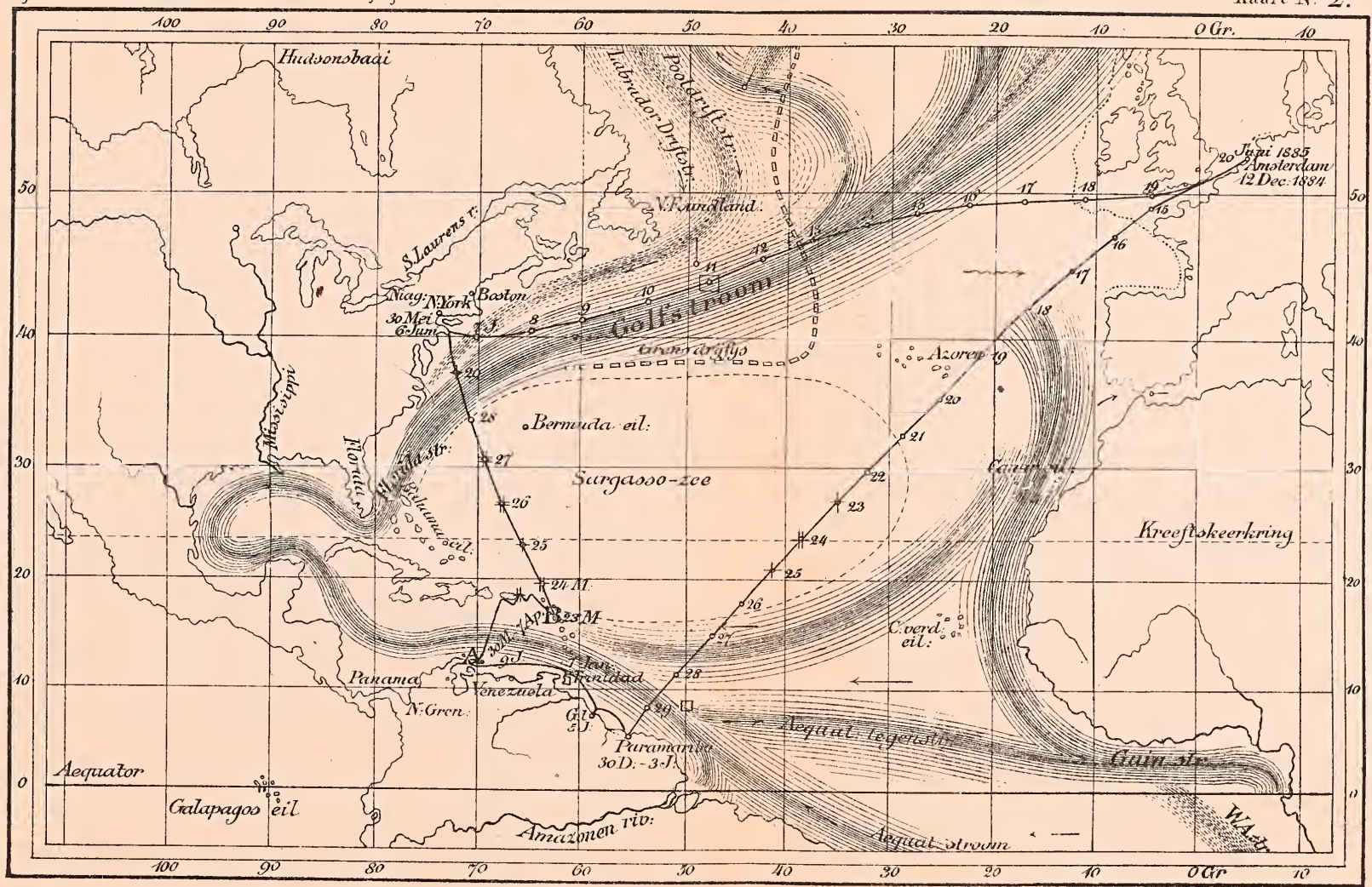

OVERZICHT der ZEEREIS. (Omtrek,stroomen enz: naar NEUMAIJER.)

$\longrightarrow$ S. koers en middagbestekken .......... grens der gronden _........ Sargasso zee. + Sargassum in vlokkien, \# S: in rÿjen,

\# Sitinvelder, $\square$ drïfÿs, A. Ned: eilander beneden, B. d" boven den wind. 
Dit alles past, met de kleine genoemde wijziging, in het door Neumayer aangeteekend areaal, gelegen in het stille gebied tusschen de armen van den grooten stroom, die, als Aequatoriaalstroom, naar de golf van Mexico, en, als Golfstroom, zich weder naar de Atlantische zee beweegt. Door dezen stroom losgerukt, en aan de binnenzijde van diens bochten afgezet, drijft het dan verder onder den invloed van den wind heen en weder.

De organisatie der plant is hiervoor gunstig. Zij bestaat uit een vertakt steelvormig loof met talrijke gesteelde luchtblaasjes die haar drijvend houden, en bladachtige uitbreidingen, die eenigzins stijf zijn, en daardoor, als de plant drijft en hare frischheid nog niet geheel verloren heeft, min of meer uit het water steken. De wind heeft er daardoor vat op.

Men ziet het wier drijven in afzondërlijke exemplaren of kleine zoden bijeen, in rijen of in soms zeer groote velden, maar dan altijd met de richting der rijen of van den langsten diameter der velden in overeenstemming met de richting van den wind.

Het spreekt van zelf; dat, bij verandering van den wind, wat richting en kracht betreft, ook de toestanden anders worden, dat de rijen en velden worden verdeeld, andere gevormd, en, dan hier-, dan daarheen verplaatst. Het kan ons dus niet verwonderen, dat zee-reizigers, die in de een of andere richting een gedeelte van het Sargasso-gebied doorsneden, nu eens geen Sargassum zagen op plaatsen, waar het door vroegere reizigers was waargenomen, dan eens omgekeerd groote opeenhoopingen vonden, waar vroegeren niets of weinig hadden gezien.

Zoo zijn ook de grenzen van het geheele gebied relatief, niet absoluut. Het over 't algemeen frequent voorkomen van Sargassum in een gedeelte der zee bewijst, dat in 't algemeen zeestroomen en wind samenwerken, om de drijvende massa daar bijeen te houden; maar het spreekt van zelf, dat wijzigingen in deze verhoudingen de grenzen beurtelings kunnen doen uitbreiden of inkrimpen, terwijl bizondere omstandigheden ook zeer goed aanleiding kunnen geven, dat weer andere gedeelten van de hoofdmassa worden verwijderd, en buiten den gewonen kring ontsnappen.

Zoo is herhaaldelijk meer oostelijk, tot aan de Canarische eilanden toe, meer of minder Sargassum drijvende gezien. Ook zuidelijker, en van daar tot in de Indische zee en bij Nieuw-Holland, en noordelijk tot aan de Europeesche kusten, van Spanje tot Engeland toe.

Van dat exceptioneel optreden buiten den gewonen kring hadden wij zelf (behalve het zeer dikwijls optreden van losse vlokken op onze trajecten tusschen de eilanden) een voorbeeld op de reis naar New-York, waarbij 
op den 26sten Mei, nadat wij den vorigen dag geen Sargassum hadden gezien, weder eenige verspreide vlokken, nog even in den golfstroom, doch aan diens buitenzijde, werden waargenomen. Het is in die buurt ook door andere reizigers, bv. Rein, gezien, en J. Agardh ontving zelfs voorwerpen van de banken van New-Foundland met wortel en fructificatiedeelen i), die hij, ofschoon eenigszins in vorm verschillende, toch tot dezelfde soort (Sargassum bacciferum) meende te moeten rekenen. Daar drijvend sargassum zelden met fructificatiedeelen voorzien is, leidde hij uit dit voorkomen zelfs af, dat de plant primitief van de New-Foundlandsche banken afkomstig zou zijn.

Dit brengt ons dus tot het tweede vraagpunt, uit een botanisch oogpunt het meest belangrijke, nl. wáár de Sargassum bacciferum oorspronkelijk groeit, en wel in zoodanige hoeveelheid, dat daaruit de drijvende wiermassa in de Sargasso-zee bij voortduring kan worden aangevuld.

De rotsen in de golf van Paria, de kust bij Caracas, de Campechebank, meerdere plaatsen in de golf van Mexico, de Florida-riffen, de Bahamabanken, de Andros-eilanden, zijn alle als zoodanig genoemd.

In den "Columbia navigator" I848 worden de Bahamabanken ten westen van Andros als de bron van groote hoeveelheden van dit wier aangevoerd. Prof. Rein, die zich eenige jaren op de Bermuda's ophield 2), houdt de Tortuga-banken, de rotsige kust der Bahama's en de $Z$. W. kust van Bermuda, waar hij het in massa heeft zien groeien, voor de oorspronkelijke bron. En laatstelijk heeft Moseley, die aan de expeditie met den Challenger deelnam, (in brieven aan Sir Hooker, Linn. Soc. Journal Vol. XIV) medegedeeld, dat hij in Harrington Sound (Bermuda) rijkelijk fructificeerende exemplaren aangetroffen heeft. Dat bij het drijvend Sargassum de vruchtorganen gewoonlijk ontbreken, is waarschijnlijk wel, gelijk Dr. Kuntze t. a. p. opmerkt, omdat deze deelen het eerst door bederf worden aangetast.

$\mathrm{Al}$ de bovengenoemde groeiplaatsen hebben zeker, in verband met de levenswijze der Sargassums en de richting der zeestroomen, groote waarschijnlijkheid; maar het ware wenschelijk, dat zij door medegebrachte

I) Om de under Korvetten, ,Josephines' ' expedition sistliden sommer (1869) insam. lade Algerne. Af J. G. Agardh, Ofrersigt af Kongl. Vetenskaps-Akademiens Förhandlingar 1870 no. 4.

2) Ueber die Vegetations-verhältnisse der Bermuda inseln. Bericht über die Senkenbergische naturf. Gesellschaft Frankf. a. M. I872-I873, p. I3I e. v., zie Kuntze 1. c. p. I98. en Just, Jahresbericht I874. II. p. II6I. 
voorwerpen werden bevestigd, ouk om de identiteit der soort te constateeren. IVat mijne eigen waarnemingen betreft, zoo heb ik - andere soor-

- ten van Sarsassım, die later te gelegener plaatse zullen worden vermeld, daargelaten - geen Sargassum bacciferum gezien aan de enkele door mij bezochte punten aan de kust van Venezuela, ook geen aan de kusten van onze eilanden onder den wind. Alleenlijk op Curaçao werd een zeer na verwante vorm aangetroffen. IVat de eilanden boven den wind betreft, werd een tamelijk groote hoeveelheid aangespoeld gevonden aan de kust van St. Eustatius, en nog meer, in zeer frisschen toestand, en op een enkele piaats ook vastgehecht, langs de kust van St. Martiu. De zee was op dat punt zeer woelig, en de exemplaren zaten te diep, om de aanhechting zelve duidelijk te zien. Slechts met moeite kon ik een enkel voorwerp, zoo laag mogelijk bij den voet afgerukt, machtig worden. Voor zoo ver ik echter kon nagaan, waren zij vastgehecht aan de onder zee gedompelde rotsb'okken.

Ik herinner hierbij, clat Mazé en Schramm, in hun „Essai de classification des Algues de la Guadeloupe (2de ed. 1870-1877, p. I36) de soort ook voor dit eiland vermelden, meest op het zand aangespoeld, maar soms ook aan de groote hoornschelpen van. Strombus gigras aangehecht. Vermoedelijk zullen er op den duur nog wel meer groeiplaatsen van dien aard gevonden worlen, hetzij primaire, van waar de groote massa van het wier afkomstig is, als secundaire, waarnaar het, van die eerste bron uit, verspreid kan worden geacht. Tot deze laatste wordt ook, mijns inziens te recht, door Mary P. Merrifield (Nature, a weekly illustrated journal of Science, Vol. XVIII. I878. p. 708) de vindplaats bij New-Foundland gebracht.

Grootere dieren zagen wij op of tusschen het Sargassum niet; alleen kleine Flustra's, Campanularia's en andere, die daarop gewoonlijk worden waargenomen.

Terwijl het Sargasso-wier een soort van windwijzer is, docrdien de rijen daarvan den wind volgen, zijn de vliegende visschen zulks eveneens, maar in omgekeerden zin, daar zij gewoon zijn tegen den wind in te vliegen.

Op denzelfden dag zaggen wij beide voor het eerst. Later waren de vliegende visschen een bijna dagelijksch verschijnsel, nu eens een enkele, dan weer kleine en groote zwermen. Hun snelle vlucht, in lange bogen, telkens het water even rakend, en hun gefladder met de groote doorschijnende vinnen, doen (Kingsley heeft ook hier het juiste beeld ge- 
troffen) als zij op u tocvliegen, aan groote paardenbijters denken. Des nachts vliegen zij niet zelden tegen het want en valien op het dek, vanwaar zij dan opsenomen worden, om, gebakken, als versnapering te worden opgregeten. Eens vloog er een, door een patrijspoort, in ons salon.

Doch, wij verlangen naar land. Reeds zien wij een eerste teeken van nadering in den Guyanastroom, dien wij dwars oversteken, en waarmede het water van de Amazonen-rivier, met slib en wat het verder bevat, in de algemeene westelijke richting van den Aequatoriaalstroom, waartoe de Guyanastroom behoort, naar de Mexicaansche golf wordt weggevoerd. Begeerig zien wij uit naar drijvende vrachten, stammen of andere plantaardige voorwerpen, maar te vergeefs. Alleen is het water kennelijk troebel en schijnt ons toe een modderreuk te bezitten. Wij denken onwillekeurig, wat miasma's wel in het heete zeebekken uit zulke stof kunnen worden uitgebroed; wij vragen ons af, of in de uitwerpsels der groote rivieren, en verderop in het drijvend en rottend zeewier, met wat claartusschen van de kust wordt weggesleept, ook mede de bron kan liggen van die gele koortsen, welke ook op de eilanden van den West-Indischen Arclipel, in zoover zij niet direct door besmetting van elders wordt overgebracht, meest het eerst aan de zeezijde en bij schepelingen op de reede schijnt te ontstaan.

Vulgens soinmige berichten is deze gevreesde ziekte echter oorspronkelijk uit Noond-Amerika, en eerst vandaar naar de Antillen en ZuidAmerika verspreid. Inclien dus e€n rivier mede de schuld moest dragen, zou het hier in de eerste plaats de Mississijpi zijn.

Maar weldra komen wij in andere omgeving, die onze aanclacht van dit bedenkclijk onderwerp afleidt en in geheel andere richting tot zich trekt.

De morgen van den $3^{\text {csten }}$ December brengt ons te half elf bij het vuurschip, dat de monding van de Suriname rivier aanwijst; een uur later bij Braamspunt. IVij zien oostelijk langs de kust het ,verbrancle bosch" en trachten, met kijkers en binocles, de Rhizophoren met haar breed uitgespreide steunwortels te herkennen. Den breeden mond der Suriname-rivier birnnengestoomd zijnde, zien wij, als eerste teeken van menschelijke bedrijvigheid, de plantage en suikerfabriek der Handelmaatschappij op den rechter oever. Bij de woningen staan bananen (Musa) met haar groenen schijnstam, uit de reusachtige bladscheeden gevormi, en haar kroon van groote langwerpige bladen. Op hooge slaike stammen wiegen kokospalmen haar sierlijke vederpluim. Roode flamingo's staan in en aan het water. Het woud langs den oever bouwt zich op in verdiepingen. Daar zien wij, hoog bovın alles uitstekend, een breede 
kroon. Het moet de katoenboom of Ceiba zijn (Eriodcndron anfractuosum); en ja, het is de bekende katoenboom van Jachtlust.

Voor dat wij het weten, zijn wij in de nabijheid van Paramaribo aan de overzijde. De toppen van huizen en gebouwen steken vriendelijk af tegen het groene geboomte. Te drie uur liggen wij voor de stad aan den steiger. Gewoon geraakt aan de stilte om ons heen, treft ons het gedruisch van honderden menschenstemmen. Negers, gereed om hunne diensten aan te bieden, negerinnen met haar bonten hoofldoek en lange stijf gesteven japonnen, treffen ons door de tegenstelling van witte kleederen bij de zwarte handen en aangezichten. Verder op, icts buiten de drukte, wandelt een groepje heeren heen en weder. De loopplank wordt gelegd. Zij komen aan boord; onder de eersten zien wij bekende aangezichten. Dr. Benjamins, oud-student der Leidsche Academie, gepromovecrd in de zoölogie, thans inspectcur van het onderwijs in Suriname; 1)r. van West, desuelijks van Leiden, geneesheer; aan andere Heeren, die ons mede verwelkomen, worden wij voorgesteld, ook aan eene commissie uit de studenten der geneeskundige school van Paramaribo.

De Heer Benjamins geleidt ons van boord. Op het cerste vernemen van ons plan, om de kolonie te bezueken, had hij naar Leiden geschreven om ons gastvrijheid aan te bierlen, waarvan wij natuurlijk gaarne gebruik maakten. Terwijl de Heer Martin en ik ten zijnent zouden logeeren, hadden zijn broeder, Mr. Benjamins en de heer Mr. van Reesema voor de jongelieden, die ons vergezelden, een plaatsje aan hun huiselijken haard maar wat zeg ik, wij zijn in achttien dagen van den winter in den eeuwigen zomer gekomen, waar geen haarden noodig zijn - onder de schaduw van hun gastvrij dak, gereed gemaakt.

Wij rijden de stad in, langs de kaai naar de woning van Dr. Benjamins, op den hoek van het Gouvernementsplein. Wat zijn dat voor boomen, op Hollandsche wijze langs den waterkant geplant, niet schoon van vorm, ook middelmatig van grootte, maar met in het cog val lend groote bladen? Het is de amandelboom, Terminalia Catappa, als hij vrij groeit, zijn kruin in twee of drie verdiepingen vormende, maar hier ook al tot stadsboom versnoeid.

Wat zijn die groote $z$ warte vogels, traag opfladderend in de naaste boomen of op de daken, om dan weer op den weg neer te strijken, en ( daar hun maaltijd aan een kreng of ander weggeworpen goedje te vervolgen? Het zijn de Stinkvogels of aasgieren (Catharthes atratus Blair), de stadsreinigers zonder patent, die zich zelven hebben aangesteld, en wier werkzaamheden claarom niet minder worden gewaardeerd. 
Over de levenswijıe van deze gieren declt Schomburgk, Reisen in British Guyana I. p. 64r, nallere bizonderheden male. Hij onderscheidt twee vormen, $C$. aura en foitens Illirg, de eerste meer vleeschkleurig, de andere meer zwartachtig op de huid van den kop. Uit eigen waarneming vermellt hij, dat deze vogel nooit levende prooi angrijpt, maar onder de doode niet juist bij voorkeur de zoodanige die reeds ontbinding vertoont; voorts verhaalt hij, hue deze vogel in bijna geheel Zuid-Amerika onder de bescherming der wetten staat, zoodat in British Guyana een boete van 50 dollars aan dengene wordt opgelegrl, die er een zou dooden. In de Savanne waren er steeds bij de hand, om het vleesch van gestroopte vogyels of de overblijfselen van den maaltijd der re:zigers te verslinden. $\mathrm{Zij}$ gingen vaak daarmede met zoo groote gulzighei: te werk, dat zij niet meer konden opvliegen, en, wanneer men hen naderde, de spijs weder moesten uitbraken om de vlucht te kunnen nemen. Nooit vond hij hunne nesten. Volgens de olgaven der Indianen bevinden zich deze in rotsspleten en legt de vogel telkens twee eieren. Maar aan de kust wordt opgegeven, dat zij op den grond, in suikervelden, nestelen.

Komt een Koningsgier, Vultur papa, in de buurt, dan verwijdert zich Ge geheele schaar Cathartes en wacht eerbiedig af, totdat de vorstelijke gast zijn maaltijd aan den, aanwezigen voorraad gedaan heeft.

Intusschen zijn wij in korter tijd, dan waarin wij dit kunnen mededeelen, aan de woning van Dr. Benjamins aangekomen.

Wij treden de woning binnen, en worden door de bevallige gastvrouw met de meeste vriendelijkheid ontvangen. Weldra gevoelen wij ons te huis, en zijn in gezellig gesprek over Holland, Leiden, de kolonie, onze plannen en wat dies meer zij, gewikkeld.

Wij treden op het balkon, en zien de rivier in hare volle breedte van meer dan een kilometer voor ons.

Links ligt het Gouvernementsp'ein, beplant met Koningspalmen (Oreoroxa regia) met hun statige, in het midden eenigszins gezwollen, boven witachtige stammen, op den top als vervolgd door de groene opstaande bladscheeden; onder deze de vertakie bloeikolven en houtige schuitvormige bloeischeeden, aan den top de reusachtige vederenbladen tot een sierlijke pluim uiteenstaande.

De bodem wordt door een grasperk ingenomen. Gele b.oemen, welke zich daartusschen in de verte vertoonen, maken mij nieuwsgierig, en ik vraag vergunning om er even heen te gaan. Met de grootste beleofdheid biedt men aan mij te vergezellen, niettegenstaande het warme uur 
van den dug. Het gras blijkt grootendeels Cynodon dactylon te zijn, met zijn fijne handvormig vereenigde aren, voor een kleiner deel Cenchrus, wier dikke blocmpakjes, met haakvormig gedorende kafjes, weldra aan onze kleeren blijven hangen. I) gele bloem is Crotalaria retnsa; ook zien wij Heliotropen (nict riekende soorten) en andere bloemen (Priva, Sicia, enz.) tusschen het gras.

Wij stcken het plein over, en komen in de laan van zware tamarinden (Tamarindus indica), die een waar sieraad van de stad uitmaakt. Op de takken rusten Tillandsia's als breede groene vogelnesten; Orchideën; Pleopeltis en andere varens. Dikke bossen van groene bladerlooze steclen met witte bessen hangen van de takken; het is de Rhipsalis Cassytha, een eigenaardige Cacteën-vorm; daarnaast, van dezelfile familie, een Phyllocactus phyllanthus met zijn platte gekartelde stengels; tegen de stammen opkruipend een Piperaceë: Acrocarpidium nummularifolium, met kleine ronde blaadjes en onaanzienlijke bleekgroene bloesem-aartjes.

Ginds staat een groote boom; hij schijnt tweeërlei loof te bezitten. Maar neen, het is een Mammie (Mammea americana), waarop een groote vijgenboom met spitse bladen en vijgjes als een kleine erwt (Ficus Schumacheri of verwante soort) zich heeft gevestigd, den stam met talrijke zware luchtwortels omwikkelend, die nu ais zooveel zuilen het dubbele gevaarte helpen dragen. - „Embraça” wordt hij genoemd, maar in de omhelzing wordt de oorspronkelijke boom niet zelden verstikt en gaat te loor, terwijl de vijg alleen op zijn stamachtige luclitwortels blijft staan.

Zcker zouden deze aantrekkelijke voorwerpen uit de tropische plantenwereld mij nog lang hebben bezig gehouden, indien niet de wachtende maaltijd ons had afgeroepen. 


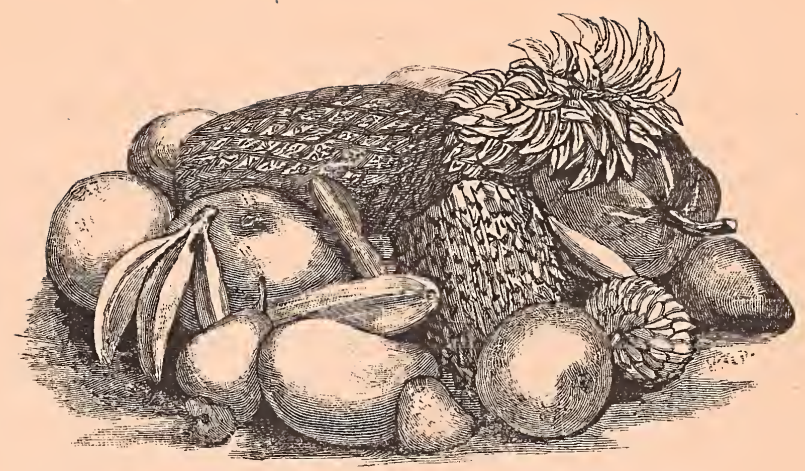

II. Tropische vruchten. Ecn zoandcling bij maneschijn. Jachtlust.

In lang hadden wij zoo rustig niet aan tafel gezeten. Nu geen stormlatten meer, nu green noodzaak om de borlen vast en in balans te houden, ten einde te verhinderen, om soep of andere artikels in den schoot te krijgen.

Op het dessert was, de beide dagen die wij in Paramaribo doorbrachten, ten onzen gevalle, een collectie van al de tropische vruchten, die op het oogenblik te krijgen waren, ter tafel gebracht, en vonden wij dus gelegenheid tot eene gastronomisch-botanische studie.

Hoezeer velen, aan de door cultuur verfijnde Europeesche vruchten gewend, deze voor de tropische, als geheel genomen, zeker niet zouden willen ruilen, zoo moet toch ieder de weelderige overvloed der tropische plantenwereld ook in dit opzicht treffen.

Met zeldzame uitzonderingen zijn het de vruchten, zoo als de wilde natuur die onmiddellijk oplevert. Welk een rijkdom van zeer uiteenloopende eigenschappen! IVelk een materiaal voor een kweekeï! Als men bedenkt, hoeveel fijne soorten uit onze Europesche appelen en peren, in hun aanvangsvormen zeker niet veel beter dan zwijnenvoeder, door teeltkeus, en bewaring en vermeerdering der goede varieteiten door enting, zijn verkregen, dan vraagt men zich af, wat wel langs dien weg uit het rijke materiaal der tropische vruchten te verkrijgen zou zijn.

Maar de tropische mensch, het troetelkind der natuur, is gewoon, dat 
hem de rijpe vruchten van ze!f in clen schoot vallen. Bevalt hem de eene niet, welnu er zijn andere, en altijl is er voorraad. En is hij niet volkomen tevreden, het dolce farniënte van het oogenblik is hem liever dan het uitzicht op hooger genot in de toekomst, met arbeid en overleg.

Fenige der tropisch-Amerikaansche vruchten zijn uit de oude wereld overgebracht. Zoo bv. de Manjo's (Mangifera indica) tot $\mathrm{I}^{1} \frac{1}{2}$ decim. groote, eenigzins platte, fraai geel en rood gekleurde steenvruchten. Wanneer het vieesch overvloedig en sappig, de steen klein, en de terpentijnsmaak, dien zij, overeenkomstig de familie waartoe $z$ ij behooren, bezitten, tot een fijnen genr is teruggebracht, is het een zeer aangename vrucht.

Fen ander lid derzeifde familie, van IVest-Indischen oorsprong, de Cachou (Anacardium occidertale) heeft een bloemsteel die tot een sappig peervormig lichaam uitgroeit, terwijl de vrucht, als een niervormige noot, daar boven op staat. $\mathrm{Zij}$ is schooner van vorm en botanisch interessanter dan aangenaam voor het gebruik. Het vruchtvleesch is zeer sappig doch flauw van smaak, eenigzins samentrekkend; waarschijnlijk door een gehalte van looizuur, maakt het sap op linnen moeilijk te verwijlleren vlekken. De schaal der noot bevat een zeer scherp vocht, terwijl de kern eetbaar is, en eenigzins aan hazelnoten herinnert.

Beter zijn de Sterappel (Chrysophyllum cainito) en zoorenoem le mispel of Sapolille (Achras supota), beile West-Indische Sapsten, welker verwanten in. Oost-Indië tot de guttapercha leverende boomen behooren. Vooral op Curaçao zijn de mispels uitstekend. Van grootte en vorm van een kleinen ronclen appel, hebben zij een grauwe schil en een zeer zoet en sappig vruchtvleesch, dat het naast aan zeer goelle vijgen, zoo als men die bv. in Italië krijģen kan, herinnert. In als een ster rondom het midde!pnnt stralenrle hokjes zit een tiental platte pitten, die zeer gemakkelijk worden verwijderd. Mij was dit, naast de Ananas - die wij overigens het best hadden in Venezuela, misschien omdat eerst daar de zon fel genoeg was on de fijne witte soort goed rijp en zoet te maken de aangenaamste vrucht.

Bananen en bacoba's (Musa) tot voedsel en als tafelvrucht gekweekt, kwamen mij voor, uit dit laatste oogpunt lang niet die verscheidenheid en goede eigenschappen te bezitten als waarvan zij, die in Oost-Indie (het oorspronkelijke vaderland), deze vruchten hebben gegeten, gewag maken. Zelfs eenige vruchten van deze soort, die jaren geleden eens in den Leidschen hortus, dus niet onder de gunstirste omstandigheden, rijp werden, waren veel beter, dan wat wij op rleze geheele reis te zien kregen. Wel werd ons verhaald van kleine zeer aangename 
bacoba's, die mij ook wel uit de door den Heer Mathes vervaardigde modellen van Surinaamsche vruchten bekend waren; maar, door welke oorzaak ook, in werkelijkheid zagen wij ze niet. In elk geval zouden de liefhebbers van deze vruchten in Suriname hunnen voorraad verrijken, indien zij eenige planten van Pisang Maas, Radjah, en dergelijke in O.-Indië geliefkoosde soorten lieten overkomen, om die, naast de reeds aanwezige, ten hunnent aan te kweeken.

De vrucht van Jambosa vulgaris, ofschoon uit O.-I. afkomstig, wordt in Suriname Curaçao-appel genoemd. Zij behoort tot de aan aromatische bestanddeelen zoo rijke familie der Myrtaceen, even als de guava (Psidium Guava), van West-Indischen oorsprong, maar in alle tropen gecultiveerd, en waarvan o. a. in Curaçao voortreffelijke vruchtengelei vervaardigd wordt.

Van geheel anderen aard is wederom de Zuurzak (Anona muricata) van de West-Indische eilanden afkomstig, een groene eivormige vrucht, 2-3 dec. lang en op de geheele oppervlakte gestekeld, eigenlijk een verzameling van ineengevloeide vruchtjes eener zelfde bloem. $Z$ ij bevat binnen de eenigzins harde schil een fijn zuur vruchtmoes. Ook andere soorten van het geslacht, Anona squamosa L. (de schub- of kaneel-appel) en Anona reticulata (Serikaja; custard-apple in de Engelsche kolonien en op onze eilanden boven den wind) leveren eveneens vruchten met eetbaar moes.

De Papaya (Carica papaya) van uit de nieuwe wereld ook naar alle tropen verspreid, wilde ons niet behagen. Voor een vrucht herinnerde de smaak te veel aan roode peen. Overigens worden, gelijk bekend, ook de bladeren van den boom gebruikt, en wel om vleesch (dat men er mede omwikkelt) malsch te maken.

Van Watermeloenen zal ik uitstellen te spreken, totdat wij met onze lezers in Curaçao, op de plantage Savonet, gearriveerd zullen zijn. En ook van andere vruchten zwijg ik thans. De lezer mocht anders soms denken, dat wij ons ree ls in de eerste dagen van ons verblijf in de tropen, door een overmatig gebruik van vruchten, hadden in gevaar gesteld, en ook hem zou de lange opsomming lichtelijk te veel worden.

Alleen moet ik nog de Advocaat (Pcrsea gratissima) vermelden, ook de alligatorpeer genoemd. Van de familie der Laurineen zijnde, kan men bij deze een fijnen geur verwachten, dien de vrucht ook werkelijk bezit, maar in een vruchtvleesch, dat veel vet bevat, en den indruk maakt van een dikken stijven room. In Oost-Indië, waarheen men de vrucht ook overgebracht heeft, wordt dit moes met maderawijn en 
suiker geklutst, tot een drank, die zcer aangenaam moct zijn. In Suriname en W'est-Ind:ë wordt het met een lepeltje uitgeschept en met peper en zout gebruikt. Ioe vreemd de inclruk zij, dien deze vrucht aanvankelijk maakt, zoo leert men haar spoedig waardeeren, en zoo wcrd ook later de gelegenheid, om haar te genieten, zelden dnor een der tochtgenooten verzuimd.

De vroege avond was inmiddels gevallen en het zonlicht had plaats gemaakt voor een schitterenden maneschijn.

Daar ons vooral een wandeling langs de plantages Ma retraite en Tourtonne achter de stad was aanbevolen, en het niet zeker was, of wij zulks den volgenden dag zouden kunnen doen, stelde onze gastheer ons voor, terstond van de gelegrenheid gebruik te maken. Zoo begaven wij ons dus op weg door de schoone belommerde lanen, en verder langs de snıalle loodrecht op elkander staande wegen, met dijkjes en sluizen en slooten (trenzen), tusschen de nu eens met bananen, dan met Cassave (Munihot utilissima), Yams (Dioscorea alata), Bataten (Batatas cdulis) of andere producten beplante en met geboonite afgewisselde velden. Het was licht genoeg, om eenige kruiden, als Cassia occidentalis en Asclepias curassarica met zijn roode bloemen en gele stempelzuil te herkennen.

Fantastisch staken in het heldere maanlicht nu eens donkere boomgroepen, dan de enkele kale stammen en de groote handdeelige bladen van re Papaya, of de kandelabervormige bloeisteng van een in een heg geplante Agave, of de doornige armen van een enkelen aangeplanten Cercus of Opuntia af.

Fantastisch dwaalden ook de gedachten over het verleden, het heden en de toekomst.

De verbeelding riep de wakkere Zeeuwen voor den geest, die in de tweede helft der r ge ceuw voor het eerst de Nederlandsche vlag in Suriname plantten, dat zij op de Engelschen harden veroverd; de WestIndische Compagnie, reeds ontworpen voor dat de Oost-Indische tot stand kwam, maar door bizondere omstandigheden eerst later opgericht en wegens tegenspoeden na een 5 ojarig bestaan ontbonden; de nieuwe West-Indische Compagnie, die weldra ook eigenares werd van Suriname, maar het, reeds een jaar daarna, onder het oppergezag van den Staat, tusschen zich zelve, de Stad Amsterdam en den Heer van Sommelsdijk, Cornelis Aerssens (als leden van de ,Societeit van Suriname”) verdeelde; deze eerste Gouverneur zonder tractement, vol ijver voor de kolonie, maar gestreng, ten gevolge daarvan eindelijk belasterd en vermoord; de 
opkomende bloei van de kolunie na de invoering van de koffiecultuu in het begin der r8e eeuw; de vestiging van Fransche émigré's, wier aandenken nog voortleeft in de namen van onderscheidene plantare's, onder anderen van die, waar wij langुs gingen; de invoer vall slaven, en al de verschrikkingen aan den slavenhandel verbonden; de oorlogen met de weggeloopen slaven en hunne nakomelingen, als boschnegers bekend; slaven-opstanden, slechts met moeite bedwongen; de opheffing der WestIndische Compagnie in 't einde der vorige eeuw; de beide kortstondige besturen van Engeland tusschen I 799 en I814, het herstel van het Nederlandsch gezag, en de verschillende uitoefening daarvan, bij achtereenvolgende reglementen, waarbij ten slotte ( 1865 ) een belangrijke invloed op clen gang der zaken aan de ingezetenen der kolonie werd toegekend; de mislukte pogingen tot invoer van Europesche arbeiders, lang voor de opheffing der slavernij in 1862; na deze, de maatregelen tot verkrijging van werklieden uit China en Britsch-Indie; de exploitatie der goudvelden aan de Suriname in de laatste negen jaren, waarbij tot dusver een waarde van $6 \frac{1}{2}$ millioen aan goud werd uitgevoer $\mathfrak{i}$; het voor de kolonie єchter nog steeds niet te ontberen staatssubsidie; de achteruitgang der suikerkultuur door de lage prijzen van dit artikel; de uitbreiding der cacao-aanplantingen, - al die feiten, hier slechts kortelijk aangestipt, doen van zelf een reeks van vragen oprijzen naar den toestand der kolonie in het algemeen en naar hetgeen daarvan in de toekomst mag worden verwacht. Die feiten brengen de moeilijkheden voor den geest, waarmede men, zoowel op de plaats zelve als in het moederland, te worstelen heeft gehad, om de kolonie tot een beiderzijds zoo gewenschten toestand van bloei te brengen, moeilijkheden, waarvan vele nog verre van opgelost zijn.

Maar op reis, onder den eersten overweldigenden indruk van het weelderig klimaat, van den vruchtbaren hodem, van een onuitputtelijken schat van natuurlijke producten, wordt men allicht optimistisch gestemd. En zoo zien wij in onzé verbeelding, al voortwandelend in den maneschijn, verschillende Nederlanders, in het bezit van zó́- of zóoveelste aandeelen in de Plantage $P$. of $Q$. in Suriname, van de nieuwe VestIndische maildienst gebruik maken, om eens na te gaan, of hunne bezitting er uitziet, overeenkomstig niet alleen met hun voordeel, maar ook met hunne eer als grondbezitters in de Nederlandsche kolonie; anderen met hen zien wij voor hun genot een winter doorbrengen in het klimaat van den eeuwigdurenden zomer; weer anderen een arbeidsveld zoeken in het ruime gebied, waarvan nauwelijks een honderdste deel in cultuur 
of exploitatie is gebracht. Wij zien de Europesche, last ons zeggen Nederlandsche bevolking (thans nog geen achthonderd op de vijf en vijftig duizend) toenemen, het verkeer vermeerderen, wegen en publieke vervoermiddelen ontstaan, wij zien een bevolking met steeds breeder opvatting van het algemeene welzijn, met een steeils sterker gevoel voor de eer der kolonie bezield; de Gouverneurs, wier gestrengheid overbodig. wordt, als vaderlijke vrienden der kolonie gewaardeerd, onafgebroken opsporend en bevorderend, wat tot den bloei cler kolonie strekken kan. Bij het toenemen der welvaart zien wij de publieke inkomsten toenemen, zoodat niet alleen het subsidie vervallen kan, maar ruime sommen aan werken van publiek nut kunnen worden besteed. Terwijl de particuliere culturen zich uitbreiden, zien wij de bosschen als koloniaal domein wetenschappelijk onderzocht en beheerd; van de vele houtsoorten zaden gewonnen, en jonge exemplaren opgekweekt op een terrein bij cle stad. Uit de $\mathrm{k} w e e k e r i j$ zien wij een uitgebreid boomspark, tot leering van een ierler en tevens aangename wandeling, ontstaan. Die boomsoorten, welke het meest gezocht zijn, worden niet enkel één voor één uit het groote mengscl van het tropisch bosch, naarmate het uitvalt, weggehakt en met moeite vervoerd, maar in grootere hoeveelheden op doelmatige plaatsen gepoot en regelmatig geëxploiteerd; alle zoo behandeld, dat zij niet alleen in de lokale behoeften voorzien, maar met voordeel kunnen worden uitgevoerd. Wij zien bij het nuttige ook het schoone bevorderd : den rijken schat van fraaie en merkwaardige gewassen der kolonie in een hortus vereenigd, kennis verspreidende onder de kolonisten en een levendig verkeer onderhoudende met de instellingen van gelijken aard op andere plaatsen en in het moederland. Kortom, vele utopiën en toekomstbeelden hielden ons, die, kersversch uit Europa gearriveerd, een wandeling in den maneschijn om Paramaribo maakten, ernstig bezig, terwijl wij. onder de fraaie mahonieboomenlaan (Sroietenia Mahagoni) huiswaarts keerden; en zij vervolgden ons nog tot in de ruime legersterle waar, onder het hooren slaan der glazen op het naburig wachtschip, bij het nog overgebleven gevoel van de wiegelingen van het schip, zich met haar herinneringen aan het t'huis in het vaderland, aan de zeereis en aan de indrukken van dezen eersten dag, op de meest bonte wijze dooreenmengelden - totdat eenige muskieten, die wel gaarne willen steken, maar buiten het ruime muskietgordijn worden afgehouden, ons in verkwiik kenden slaap hadden gevedeld.

3I December. Wij bezochten heden morgen te 9 uur den Gouverneur, 
J. H. A. W. Baron van Heerlt tot Eversberg, bij wien wij gisteren claartoe belet gevraagil ha.llen, en die ons al aanstonds door middel van zijn zoon, plaatsvervangend Adjudant, had uitgenoodigd tot een tocht langs de Para-rivier op I en 2 Januari. Waren wij door deze uitnoorliging, die onze stoutste wenschen betreffencle de besteding van het korte oponthoud in de kolonie overtrof, reeds van zijne belangstelling en vriendelijkheid overtuigd, nog levendiger werd die indruk door de persoonlijke kennismaking. Op het cogenblik dat ik dit schrijf, is de Gouverneur reeds weder in het land en door een andereu vervangen. In een stuk in een der Surinaamsche dagbladen, overgenomen door het Nieuws van den Dag, las ik deze wourden: „De baron van Heerdt tot Eversberg heeft zich door getrouw en, waar het moest zijn, streng plichtbesef onbemind gemaakt, maar zijn naam zal hier in eere genoemd blijven." Waarlijk, eene uitspraak, waarop men trotsch mag zijn. Ons heeft hij, door zijne voorkomendheid en hulp, grootelijks aan zich verplicht.

Van de marmeren achteryalerij in het paleis, waar wij op recht ongedwongen wijze ontvangen werden, heeft men het uitzicht op een kleinen maar netten tuin, waarin men langs eenige trappen nederdaalt. Daarachter komt men, over een brugje, in een ander terrein, dicht met boomen bezet, dat vroeger ook tot den tuin van den Gouverneur behoorde, maar thans tot publieke wandelplaats is ingericht. Het spreekt van zelf, dat het niet lang duurde, of de gesprekken werden in dien tuin voortgezet, waar een prachtig bloeiend exemplaar van Pachira aquatica, schoone Codiucum, Orchidcen en andere planten als om strijd bekeken en bewonderd werden. Nadat wij eindelijk van den Gouverneur afscheid hadden genomen, vergezelde mij diens zoon nog langen tijd in het h.alf wilde bosch daarachter, waar ik onderscheiden boomen leerde kennen, en eene verzameling maakte van de blad- en levermossen, die in dat goed beschaduwd en vrij vochtig terrein op de stammen van deze voorkwamen.

Verder werd de dag besteed met wat in de stad rond te zien. Zij is doorsneden met breede, schoon beplante lanen. In het midden der stad staan de huizen, met steenen onderbouw, verder van hout en met houten pannen (singels) gedekt, dicht naast elkander, zoodat alleen in het midden der blokken ruimte voor tuintjes en tuinen overblijft. Meer naar den imtrek zijn zij eenigzins als villa's ingericht. Onder de sierplanten werkte ik op: verschillende Palmen, Dracaena's en de reeds genoemde odiacum in fraaie exemplaren met ronde gevulde kroon op stam, I a 2 meter hoog, wegens haar hangende lange en smalle rood- en witbonte bladen hier "Apenhaar" genoemd; "Reseda," een heester, zoo genoemd 
wegens den geur zijner bloemen, in werkelijkheid echter een Lythrarice, Lazusonia inermis, de "Henna" van Indië en Aegypte; Plumicra, Poinccttia, Passiflora quadranguluris en anderen.

Vóór de bloemen in de tuinen fladderden tal van colibri's.

Onder de boomen in de stad mag ik niet onvermeld laten groote Mangifera indica, met haar dichte donkere kroon, en opstaande bloemtrossen, terwijl de vruchttrossen later door de zwaarte der vruchten nederhangen. Het is een prachtige schaduwboom. Voorts een Wilg met smalle bladen en stijf opstaande takken, Salix Humboldtiana, die hier echter nog niet fraai ontwikkeld was. Ook zagen wij hier en daar een Vlier (Sambucus canadensis) wat eerst een 7.onderlingen indruk maakte, vooral omdat hij zeer op onze gewone Vlier gelijkt.

In den leop van den avond werd ons eene serenade gebracht door de studenten der genesskundige school. Deze inrichting, sedert 5 of 6 jaren bestaande, ten eincle ann de behoefte van voldoende geneeskundige hulp op de plaatsen buiten Paramaribo zelf te voldoen, werd opgericht met de krachten clie de kolonie zelf opleverle, en telt thans een dertigtal leerlingen. Het ontbrak natuurlijk niet aan hartelijke wederkeerige wenschen voor den bloei der Leidsche Academie, van deze betrekkelijk jonge inrichting in de kolonie en van het onderwijs aldaar in het algemeen. De kolonie telt over dë 5000 schoolgaande kinderen, voor welke II 2 onderwijzers en onderwijzeressen in de stad en in de districten werkzaam zijn. Dat de ijverige inspecteur daaraan gaarne nog meer uitbreiding, ook wat betreft de leervakken, in aansluiting aan een later onderwijs op de genoemde geneeskundige school, gegeven zou zien, is zeer natuurlijk, en wij hopen, dat hij langzamerhand zijne wenschen in dit opzicht vervuld moge zien.

Een deel van de muziek der schutterij verzelde de serenade, die ons met haar fakkellicht, het rumoer op straat, en den kring van gasten in het salon van onzen gastheer, eenigermate in de Leidsche toestanden verplaatste. Verder was de avond zeer gezellig en werden wij daarbinnen op muziekale voorilrachten vergast, die wij, eerlijk gezegd, zoo vuortreffelijk niet in de kolonie hadden verwacht. Ook een concert van het muziekgezelschap "Sempre crescendo," dat den $3^{\text {den }}$ Januari gegeven werd, en dat men ten onzen gevalle tot deze dagen had uitgesteld, gaf daarvan ruimschoots getuigenis.

In 't algemeen maakten de kolonisten, naar hetgeen wij in deze korte dagen zagen en hoorden, op ons den indruk van een pittig volkje, niet gemakkelijk te regeeren, zoowel met de deugden als met de gebreken 
van een kleine ecnigszins gcïsolecrle maatsciappij behebt, zeer vrijmoedig in $\mathrm{h} \in \mathrm{t}$ oordeclen, maar ook weerkeerig vrijmoedigheid in dit opzicht kunnende verdragen (en zij zullen mij dus ook zeker het aanrocren van deze punten niet $k$ walijk nemen), voorkomend en gastvrij, intelligent en vatbaar voor geesttrift, gaarne hun werk- en denkkrachten overhebbencle voor de kolonie, waar zij van eenig belang overtuigd zijn, nu en dan ietwat anti-gouverneurgezind, en dit ook niet onder stoelen of banken schuivencle, maar toch in hun hart meer gehecht aan het Nederlandsche bestuur dan aan het Staats-subsidie, wat zij gaarne overbudig zouden zien; een vereeniging van verschillende, deels welliclit, althans schijnbaar, tegenstrijdige eigenschappen, maar waarvan, behoorlijk geleid en gesteund, op den duur veel goeds kan worden verwacht en verkregen.

Onder hen bezit de kolonie, in verschillende betrekkingen, een, in verhouding tot haar blanke bevolking, niet onbelangrijk getal oudacademie-burgers der Nederlandsche Hoogescholen. In de baan der wetenschap, in den omgang met geleerden en jongelieden van verschillend karakter en aanleg, aan een breeclere levensopvatting gewoon geraakt, geleerd en niet verleerd hebbende, het utile met het dulce te vereenigen en bij scherts en luim den ernst van het leven niet te vergeten, vormen zij een element in die kleine maatschappij, welks waarde daarvoor niet gering mag worden geschat. Ik noem hen oudstudenten, ook in herinnering aan den alleraangenaamsten dag, dien wij, op 3 Januari, in hun midden doorbrachten op de Plantage Jachtlust, van den Heer Mr. G. A. Barnet Lyon. Met hem waren het de Heeren Mr. H. Benjamins, Dr. H. D. Benjamins, Mr. A. H. A. M. H. Borret, na zijn studie in de Rechten tot den geestelijken stand overgegaan. Dr. M. C. de Leeuw, Mr. C. I. Helicly, Mr. A. J. Jessurun, Mr. D. Juda, Mr. J. Kalff, Dr. A. Salomons, Mr. F. Siewerts van Reesema, Mr. W. A. van Emden, Dr. C. van Lier, Mr. C. H. van Meurs en Dr. J. van West, die ons alle in bovengenoemde qualiteit daartoe hadden uitgenoodigd.

In een cacaoboot, anders bestemd om de producten van de plantage af te voeren, werden wij, onder hevige plasregens, maar die aan de gezelligheid geen afbreuk deden, naar de overzijde getransporteerd. Wij traclen de vriendelijke woning binnen, maakten een wandeling door de plantage en het aangrenzend bosch, zagen van nabij dien reus der woudreuzen, den Ceiba of katoenboon (Eriodendron anfractuosum), dien wij reeds vroeger uit de verte hadden gezien, beschouwden de Cacao- 
aanplantingen, I) en zaģen onderscheid(ne interessante planten in het wild.

Onder anderen verzamelden wij de Matrozendruif (Solanum mammosum) wier wortel met de stengels van Louise Bciberie (een composiet: Eclipta alba) en den wortel van Sabanaboontjes - een plant waarvan ik geen exemplaar kon verkrijgen en dus ook den wetenschappelijken naam niet opgeven - als een middel tegen slangenbeet wordt gebruikt.

Daar later in tegenwoordigheid van de $\mathrm{HH}$. Martin en van de Poll, die met een paar ratelslangen uit Aruba naar Suriname waren teruggekeerd, een proef met deze door een inboorling werd genomen, laat ik aan deze medereirigers de narlere beschrijving van de bereiding en applicatie van het middel en het uiten van eene opinie over zijne deugdelijkheid over.

Ook maakten wij hier kennis met het snijdend riet (Seleria flagellum) dat met zijn dunne stengels en smalle bladen tusschen de boomen opklimt, en een groote hindernis bij het gaan door het bosch oplevert. Voorts een Mertensia, Adianthum en andere varens, Cassia alata enz.

Aan het gezellig feestmaal, in een pauze waarvan een der koelies, op de plantage werkzaam, ons op acrobatische toeren onthaalde, werd natuurlijk menige dronk aan Nederland, zijn Hoogescholen en wederkeerig aan de kolonie en de vertegenwoordigers van de verschillende vakken van wetenschap in de kolonie gewijd. In opgewekte stemming werd de terugtocht aanvaard en volbracht.

Doch keeren wij tot $3 \mathrm{I}$ December terug. Tot lat doorkruisten wij op den oudejaarsavond de stad, die bij gelegenheid van dit feest bizonder levendig was, zagen in de wijk waar de Chinezen wonen, vuurwerk afsteken bij kisten vol te gelijk, zagen de ne-rers hun schuivende dansen uitvoeren, opgepakt in een kleine ruimte op eentoonige muziek, waarbij de trommel den hoofdtoon voert, werlen gastvrij ontvangen in menig huis, ontvingen en gaven nieuwjaarwenschen op menig balkon, waar men haast niet scheiden kon van het heerlijk uitzicht in den schitterenden maneschijn, totdlat ons verstand ons zeide, rust te nemen voor den volgenden dag.

I) Zie over de cultuur en bereiding der Cacao in Suriname een uitvoerig artikel van de Heeren E. J. Bartelink en Baron Schimmelpenninck van der Oye in het (7) Tijdschrift, uitgegeven door de Maatschappij ter bevordering van Nijverheid, 4. IV. p. 305 en 337 e. v. 
III. De Para.

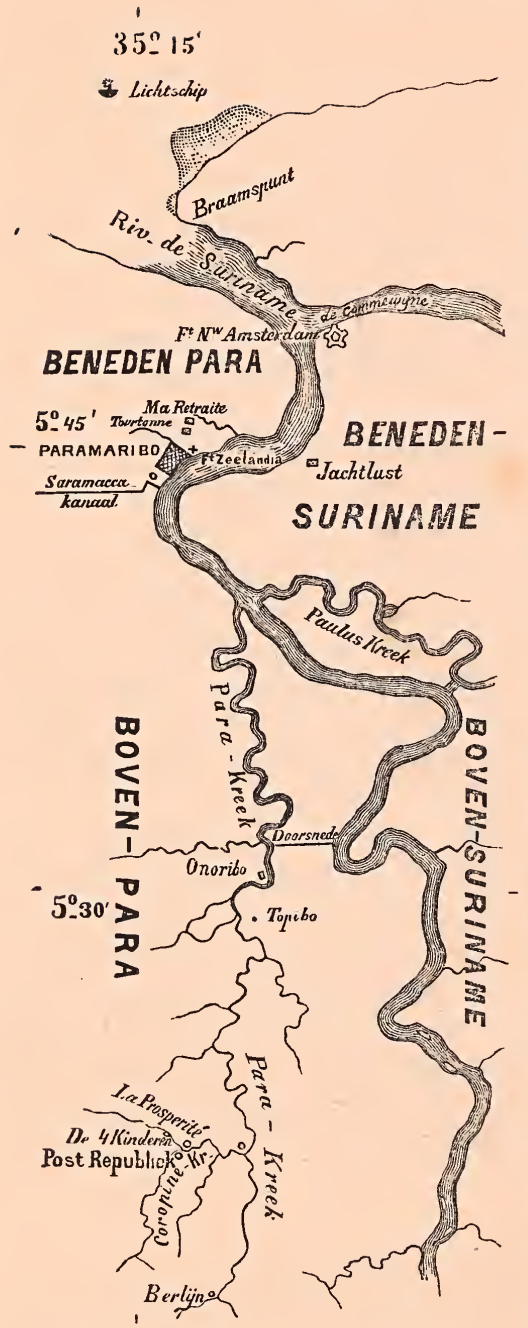

De morgen van het nieuwe jaar vond ons te 6 uur aan de kani, waar twee stoombarkassen, le Creool en de Elilorado, gereed lagen, om het gezelschap voor de Para, den Gouverneur, diens echtgenoote, zoon en schoondochter, en verdere autoriteiten en gasten op te nemen.

Onder deze waren de Heer A. J. Baron Schimmelpenninck van der Oje, administrateur van finantiën, waarin ik het genoegen had een ouden schoolvriend te herkennen, eene ontdekking die, toen zij plaats had, door den Gouverneur met een hartelijken feestdronk werd bezegeld; de Overste de Haan, Commandanit van het Nederlandsch oorlogschip de "Suriname," de Heer J. F. A. Cateau van Rosevelt, agent-generaal van het immigratie-departement, de welbekende vervaardiger van de groote kaart van Suriname, op de Amsterdamsche Internationale tentoonstelling bekroond, en wiens onvermoeide 40 jarige werkzaamheid in de kolonie weldra met erkentelijkheid zou worden herdacht, Dr. Benjamins, de Heer

C. N. Kaersenhout, districtcommissaris van de Boven-Para, de Heer Loth, gouvernements landmeter, benevens de Heeren Barge en Gorsira uit Curaçao, tijdelijk in Paramaribo.

Aanvankelijk voeren wij de Suriname op, passeerden het kanaal, dat 
de Suriname met de Saramacca verbindt, om weldra de Parakreek, die aan de westzijde in de Suriname valt, op te stoomen.

Dit riviertje, waarvan de verste tak op de hoogte van Berlijn, 50 Kilometers, dus ongeveer 8 uur gaans, zuidelijk van Paramaribo ontspringt, loopt met vele kronkelingen, waarbij het eerst de Coropine-kreek, en verder nog andere kreeken opneemt, van zuid naar noord, ongeveer evenwijdig met de Suriname-rivier. Niet ver van Onoribo, waar zij het dichtst bij deze rivier komt, heeft men haar door een ongeveer 4 kilometer lang en recht kanaal of doorsteek daarmede verbonden, een kanaal, dat, van weerszijden door de oeverboomen overgroeid, onder welker bogen in de verte het daglicht zichtbaar is, bij het voorbijvaren een zeer schoon gezicht oplevert.

Het spreekt van zelf, dat ook het riviertje, in den aanvang, van de Suriname af gerekend, nog redelijk breed, hoe langer des te smaller wordt, naarmate men den oorsprong nadert: de oevervegetatie komt van weerskanten tot elkander, en eindelijk vaart men onder een gesloten loofdak. In de omgeving van de Triangel, de plaats waar de Coropinekreek in de Para valt en waar wij deze laatste invoeren, zijn beide in dit opzicht hoogst schilderachtig.

De geheele vaart is, gelijk een der tochtgenooten opmerkte, eenvoudig een vaart langs een riviertje door een bosch. Maar welk een bosch? Het tropische woud, reeds zoo dikwijls met levendige kleuren geschilderd, maar de aanschouwing waarvan de geheele moeite van de reis naar Suriname beloont.

Hem, die aan de Europeesche bosschen gewoon is, treft het tropisch woud onmiddellijk door de groote verscheidenheid van zijne bestanddeelen.

Een beuken-, een eiken- of dennenbosch, dus hoofdzakelijk uit één boomsoort bestaande, maakt, wanneer het uit zware exemplaren is samengesteld, een grootschen, om zoo te zeggen deftigen indruk. Onopgesmukt staat het daar in zijn aristocratische grootheid. Overal dezelfde vertakking, hetzelfde loofdak. Hoogst eenvoudige bloesems, wier stuifmeel, vaak in overvloedige wolken, over het geheele woud wordt uitgestrooid. Van de zaden, op den grond nedergevallen, ontkiemt een grooter of kleiner deel, maar slechts weinig daarvan groeit hooger op. Doorgaans is er opslag van ander onderhout, uit zaden van elders aangekomen. Eveneens onderdrukt, streeft het echter voortdurend er naar, de plaats van den onderdrukker te veroveren. Het slaagt daarin ook op den duur, naarmate de oude stammen vallen en vermolmen. Het eikenbosch, aan 
zich zelf overgelaten, wordt sparrenbosch of beukenbosch of omgekeerd, en zoo wisselt de eene overheersching de andere af.

Het tropisch bosch daarentegen bestaat tegelijkertijd uit een groot aantal soorten van boomen, die tot de meest verschillende geslachten en famillien behooren, elk dus met zijn eigenaardig karakter van bloemen en blad, en ook elk verschillend van vorm en grootte.

Als in verschillende verdiepingen opgebouwd, heeft het zijn heesters, zijn boomen, deze weder op verschillende hoogte hun kruinen verheffend, zijn epiphyten, zijn slingerplanten. Onder de vormen van vertakking en loof vinden wij onderscheidene die aan onze Europeesche vormen herinneren. Een sterke tegenstelling vormt het gemis van naaldboomen en het optreden daarentegen van Palmen, Pisangachtige gewassen en andere tot de éénzaadlobbigen behoorende plantenvormen.

Eindelijk zijn de boomen in het algemeen hooger, 15-25 meter is niet zeldzaam: de hoogste vormen klimmen tot 50 meter en meer.

Het spreekt overigens van zelf, dat ook het tropisch woud niet overal hetzelfde karakter vertoont.

Waar de boomen dicht opeenstaan, en met haar kroonen een gesloten loofdak vormen, beletten zij, even als in onze hoogwouden, het grootste gedeelte van den ondergroei. Behalve mossen en varens op neergevallen stammen en takken, op den bodem, ziet men dan, tusschen de hoog onvertakt opgaande stammen, vooral lianenstengels, die in lissen opwaarts stijgen, en lange luchtwortels die van uit de hoogte nederhangen. Zulke partijen - het klassieke oerwoud - zijn o. a. door Splitgerber, die Suriname een veertigtal jaren geleden bezocht, ook in het Para-district, achter Berlijn, waargenomen en beschreven.

Een dergelijk vegetatiebeeld, op beperkte schaal, zullen wij ook later aantreffen in den krater van St. Eustatius.

Daar heerscht niet ééne boomsoort met uitsluiting van alle andere, maar hebben al die woudreuzen zich tot onderdrukking van kruiden en heesters en lager geboomte vereenigd.

Hier echter, op den tocht langs de rivier, die reeds van zelve een open lijn in het bosch vormt, en aanleiding geeft tot de ontwikkeling van boschrand en oevervegetatie, in een streek, waar ook over het geheel het bosch niet zoo dicht en zwaar is als hoogerop in het binnenland waarvan mijn reisgenooten de Heeren Martin en Van de Poll, die later de Boven-Suriname bezochten, uit eigen aanschouwing zullen kunnen gewagen - is de indruk een andere, namelijk van minder statige maar meer weelderige en veelzijdige ontwikkeling. 



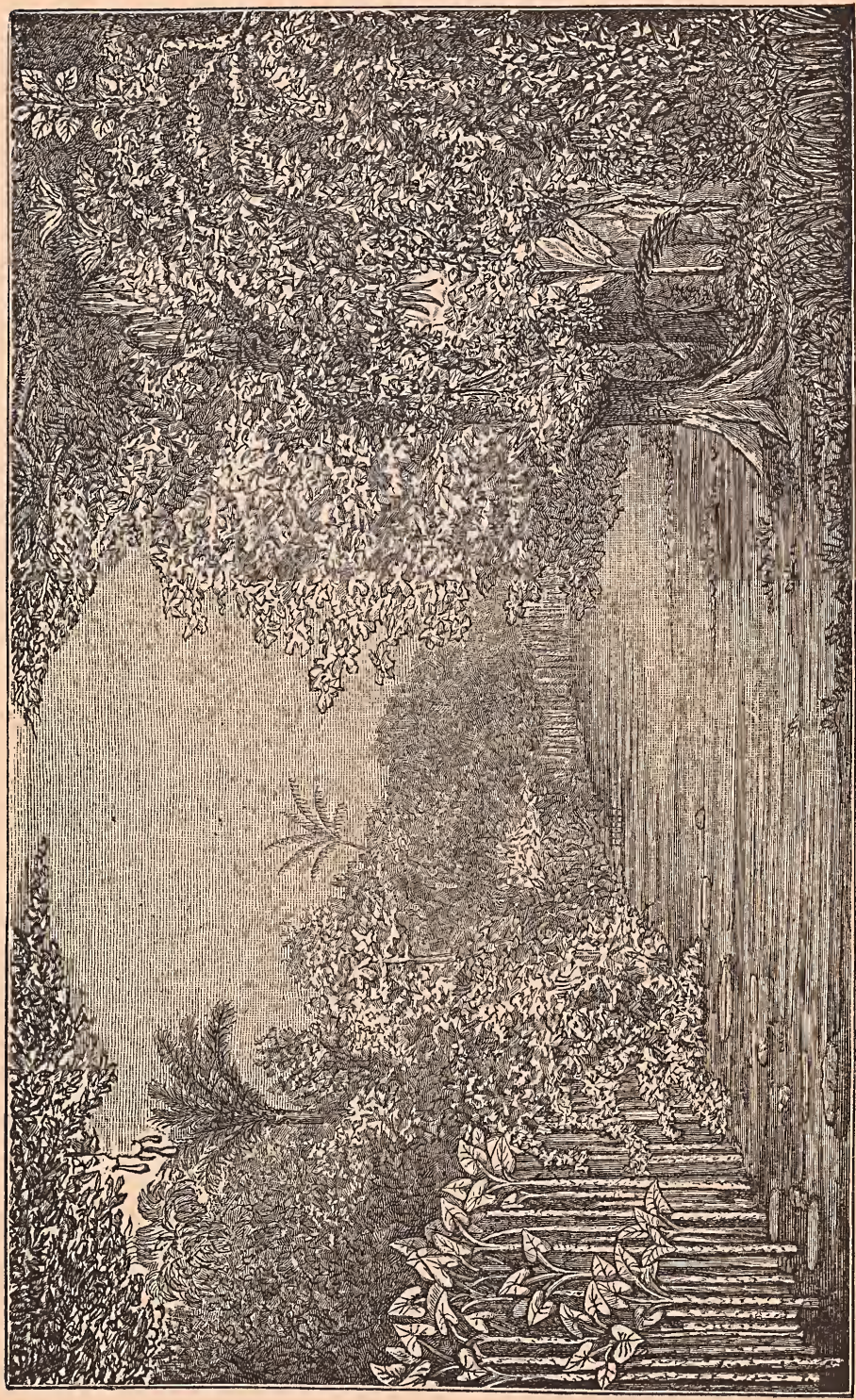


De redeneering leert ons, dat het ook hier aan strijd niet ontbreken kan. Tal van kiemen moeten in den grond verborgen liggen, wachtende op een gelegenheid tot ontwikkeling. Wat groeit tracht naar uitbreiding, naar vermeerdering, en wat wij waarnemem is een toestand van evenwicht. Maar die strijd schijnt meer een persoonlijke wedijver, geen strijd en uitsluiting van klasse tegen klasse. - Voor alles schijnt plaats en gelegenheid te zijn, zich overeenkomstig zijn natuur en aanleg te ontwikkelen, en het zijne bij te dragen tot de vorming van een schoon en harmonisch geheel.

Daar staat, langs den oever, met zijn rechte drie tot vijf meter hooge onvertakte doornige stammen en krans van breed pijlvormige bladen op den top, de Moko Moko, Montrichardia aculeata, ook wel als varieteit van zijn doorgaans zwakkeren en niet zoo gedoornden broeder Montrichardia arborescens beschouwd.

Als soldaten staan zij in het gelid, lange streken innemend, in of naast het water.

Waar zij onmiddellijk aan den oever staan en de rivier onder den invloed van eb en vloed daalt en rijst, ziet men vooral op hunne kale stammen die streep van door het hoog water achtergelaten slijk, welke tot de uitdrukking "touwslaan van de rivier" heeft aanleiding gegeven.

Elders vertoont zich aan den oever struikgewas, zoover het water ziltig is, de over het water nederliggende ,branti makka”, een doornige Papilionacée met trossen van kleine paarsche bloemen en kromme peulen (Drepanocarpus lunatus); andermaal de stijf opstaande Hibiscus bicornis, met zijn groote roode Malva-bloemen.

Van de heesters en het naburig geboomte hangen de slingertakken met tweetallige bladen en trossen van groote roode bloemen en lange peulen, van Bignonia incarnata.

Tusschen hen mengen zich de gele trompetbloemen en doornige ronde vruchten van een slingerheester uit de familie der Apocyneën, Allamanda catharctica.

In stille hoekjes staan cypergrassen met schermvormig vereenigde aartjes en lang uitstaande omwindsels (Cyperus ligularis, elatus, luzulae); ook groepjes van een Amaryllidée met witte bloemen (waarschijnlijk Pancratium).

Over het water breiden zich van den oever grassen uit, die met haar lange uitloopers de kreek dreigen te vullen, en die dan ook, vóbr den tocht, op last van den Gouverneur, zooveel mogelijk door de aanwonende bevolking waren verwijderd. De bloesempluimen verraden dat het Panicumen Paspalum-soorten zijn: Panicum molle, Hymenachne myurus, Paspa- 
lum conjugatum met zijn twee bloemaren aan het einde van den stengel, Paspalum densum met een dichte bloesempluim. Een Polygonum (Polygonum macrochaetum (door groeiwijs herinnerend aan onze Polygonum amphibium, maar met de spichtige aren van Polygonum hydropiper), mengt zich daartusschen.

Hooger op, waar het water koffiekleurig wordt door den humus, drijven Nymphaea ampla en Rudgeana, bladen en bloem van de grootte onzer waterplompen, Salvinia auriculata, Pontederia crassipes, haar opgezwollen en met lucht gevulde bladsteelen als zwemblazen gebruikend. Ook een Marsilea vertoont zich met zijn viertallige op het water drijvende klaverblaadjes, en de Elodea grianensis, zuster van de bij ons bekende "waterpest" uit Canada, maar met smaller bladen en tweeslachtige bloemen.

Tusschen het hout aan den oever, iets meer op den achtergrond, komen "wilde banannen" (Heliconia) met haar breede langwerpige, een paar meters lange bladen, en eindelingsche tros met roode in twee rijen afstekende schutbladen, waarbinnen zich de onaanzienlijke bloemen verbergen, voor den dag. Voorts klimpalmen (Desmoncus polyacanthos) met slanken stengel en gevinde, in doornige ranken uitloopende, bladen. Ook hooger op een enkele Bactris, een stamlooze palm met zeer groote, eveneens gedorende vederbladen.

Het is bekend, dat de kolonie meerdere van deze kleine doch schoone palmen bezit, die bij de inboorlingen als Paramakka, Keeskeesi-maka, Pienga-maka enz. bekend zijn, maar omtrent de wetenschappelijke namen van de soorten, die hiermede bedoeld worden, zijn de opgaven van Miquel, de Vriese en anderen niet geheel eensluidend.

Dit is dus reeds een van de vele gevallen, waarvoor het wenschelijk zou zijn, van verschillende lokaliteiten rijpe zaden in te zamelen, en ze daaruit, te Paramaribo, met nauwkeurige aanteekening van de inlandsche namen en groeiplaatsen, aan te kweeken.

Daarvoor zou allicht een plaatsje kunnen worden gevonden, ook al wordt de wensch, nog laatstelijk door Westerouen van Meeteren, in zijn opsomming van "Surinaamsche planten en cultuurgewassen" (Amsterdam r883) uitgesproken en dien ik gaarne deel, nl. dat Paramaribo zich weldra, evenals Georgetown, in een proeftuin, met daaraan verbonden botanicus zal mogen verheugen, nog niet onmiddellijk vervuld.

Wij makten reeds melding van sommige heesters en ranken langs den oever. Het verdere hout, van verschillende hoogte, vertoont nu eens den enkelvoudigen laurierbladvorm, dan dien van gevinde bladen als van 
Esschen, niet zelden den dubbeldgevinden fijnen Mimosa-vorm, ook het handdeelig of handvormig samengestelde blad.

Hier en daar verschijnt aan den oever, als vertegenwoordiger van het laatste, de Pachira aquatica, een boom van middelmatige grootte met dichte kroon van groote bladen, die eenigzins op die van onze Paardenkastanje gelijken, en bleekgele trechtervormige bloemen van een paar decimeter grootte, waaruit een onnoemelijk aantal lange, beneden tot bundels vergroeide meeldraden naar voren steekt. Het is een van die boomen, welke aan de bovenzijde van hun wortels plankvormige verhevenheden vormen, die, van den stam uitstralend, dezen tot steun schijnen te verstrekken. Wegens den vorm en grootte zijner langwerpige vruchten wordt hij "wilde cacao" genoemd. Een andere, nu en dan boven het kreupelhout uitstekende vorm is de "wilde papaya" (Cecropia peltata) met zijn groote handlobbige bladen tot een kleine kroon op den enkelvoudigen, overigens kalen, of met enkele, loodrecht afstekende en kandelabervormige opgebogene takken voorzienen stam vereenigd.

Een belangrijk aandeel in het landschap hebben de boomen met gevind blad of dubbelgevind zoogenoemd Tamarindenloof. De Knippenboom (Melicocca bijuga), Inga's, Calliandra's, de boschtamarinde (Mimosa guianensis) vormen groote en schoone boomen, welker bladkroon vaak de rivier met een fraai gewelf overdekt; de sierlijke Mimoseënbloesem in hoofdjes, die op het eerste gezicht alleen de talrijke lange meeldraden als kwastjes van fijne haren doet zien, heeft ook bij de negers bewondering gevonden. Een Mimoseën-heester, verwant aan Pithecolobium adianthifolium, draagt wegens hen den naam van "keri wiki wjatki' d. i. "de geheele week gekleed."

De half vlinderachtige bloem der Caesalpineen vindt een vertegenwoordiger in het Watergroenhart (Vouapa simira) en in het bijlhout (Eperua falcata) waarvan de platte sikkelvormige peulen aan lange steelen boven ons hoofd hangen.

Maar de boomen dragen niet enkel hun eigen bloemen en vruchten. Ginds wiegt zich een Orchidée op een tak, daar hangen bossen Rhipsalis, elders wordt een Phyllocactus, een varen, of worden zware Tillandsia's veilig in de lucht gedragen. Tegen stammen hoog opgroeiend zien wij Aroideern (Philodendron).

Het uitzicht opent zich weder. Daar steekt op een afstand de spichtige, ijle kruin van een Mierenboom (Triplaris) met zijn groote lancetvormige bladen omhoog. In zijn holle stengelleden huisvest hij tal van mieren. De boom is een Polygonée, verwant aan onze boekweit, eene dier boom- 
achtige vertegenwoordigers van plantengroepen in de tropen, welke bij ons slechts kruidachtig voorkomen. Ook de grassen leveren daarvan een voorbeeld in het bamboes, waarvan wij een enkelen stoel, bij het invaren in de Parakreek, aan haar oever zagen groeien.

$\mathrm{Nu}$ en dan verheft een Ceiba (Eriodendron anfractuosum) zijn breede kruin over al het geboomte. Wij zouden hem den koning van het woud noemen, indien die titel niet reeds door Linnaeus aan de palmen was toegekend.

Inderdaad verleenen deze een hoogen glans aan het tropisch landschap.

Wij zagen hier de Maripa-palm (Maximiliania regia) met zijn sierlijke kroon van groote vederbladen, de hooge slanke Pina of Palissade-palm (Euterpe oleracea) eveneens met vederbladen, maar waarvan de slippen stij kamvormig nederhangen; voorts, meest in groepen gezellig vereenigd, de Mauritia-palm (Mauritia flexuosa) met kroon van groote waaierbladen.

Linnaeus noemde ze vorsten, principes. En zijn zij vorsten, dan zijn zij goede vorsten. Hun kroon, hoog verheven boven het omringende woud, dat zich gewillig aan hen schijnt te onderwerpen, strekt dit niet tot last maar tot hoogste sieraad.

Van dierlijk leven bespeuren wij niet veel. Wij zien de groote onregelmatig kegelvormige mierenesten der zoogenaamde houtluis, met communiceerende loopgangen langs de boomstammen. Ook hangen in de boomen, vooral de broodboomen (Artocarpus) in de nabijheid der woningen, de zakvormige nesten van troepialen (Cacicus), een vogel uit de spreeuwenfamilie. Door het water schiet een enkele waterslang. Wij worden opmerkzaam gemaakt op den muskusreuk, dien een Boa constrictor verspreidt, en doen al ons best, om iets van de reuzenslang te zien. Doch het grootste gedeelte blijft onder water. Alleen een visch "met vier oogen" die juist voorbij zwemt - het tweede paar oogen zullen wel neusgaten geweest zijn - kijkt ons wonderlijk aan. Een witte reigerachtige vogel duikt

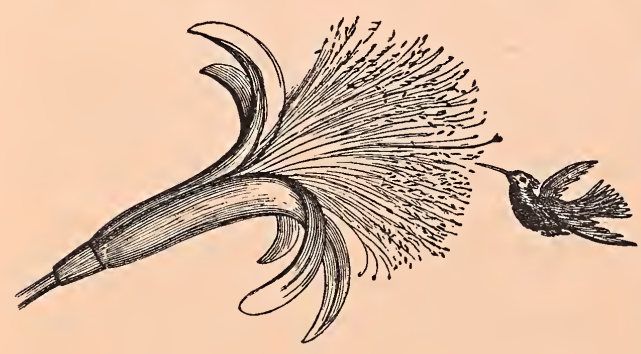
onder water, en voor de groote bloemen der $\mathrm{Pa}$ chira fladdert een $\mathrm{Co}$ libri, als een groote nachtvlinder, gereed om de insecten, die daar hun nuttig werk van opvangen en overbrengen van het stuifmeel komen verrichten, met 
den spitsen snavel weg te snappen. Des nachts zien wij de vliegende vonken van lichtkevers. Doch ook overdag hooren wij niets dan het geluid van onze vaartuigen, onze eigene gesprekken, en nu en dan het gefluit van een troepiaal.

Maar neen, daar knallen geweerschoten. Achter den kruiddamp, uit een tot dusver niet zichtbaar boschpad, springen twee zwarte gedaanten te voorschijn. - Er is geen gevaar bij. Het zijn de negers, houtverzamelaars daar ter plaatse, die den Gramman (Gouverneur), bij zijn doortocht met vreugdesehoten begroeten.

Waar wij aan land stappen, eerst op Onoribo, om te dejeuneeren, knalt een kanonschot en komt de geheele negerbevolking te voorschijn, juichende, dansende en in hun zangen de gezondheid van den gouverneur bezingende. Allen hebben toilet gemaakt. De japonnen der negerinnen zijn zoo mogelijk nog stijver dan anders, en staan naar alle kanten uit.

Fen der negers heeft een kartonnen steek op, een rok aan, met goudpapier beplakt, en goudpapieren epauletten op de schouders. Wij kunnen een glimlach niet onderdrukken. Maar stil! het is een ernstige zaak. Met groote deftigheid gaat hij de anderen voor, en geleidt het gezelschap naar een eerepoort van groen en bonte strikken, die voor den gouverneur en de zijnen is opgericht. De vrouwen breiden bonte doeken voor hunne voeten uit.

Wij gaan over een open grasvlakte, een kleibodem, waarover de Para zich in den regentijd: verbreedt, vrij dicht bezet met Cynodon dactylon, op lagere plaatsen met Cypergrassen (Kyllingia monocephala) op hoogere met Cenchrus echinatus vermengd - een weide vormend waarop koeien grazen - naar de woning van den rentmeester Flu, waar het dejeuner in gereedheid is gebracht.

Daarna maken wij een kleine wandeling achter de woning, waardoor ons een blik vergund wordt in de Savanne, een iets hooger liggende zandgrond, die deels open, deels met bosch en heesters bezet is.

Een aantal negerhutten, uit planken gebouwd, en met palmbladen gedekt, ligt er onregelmatig verspreid, met een meer schilderachtig dan welvarend uiterlijk.

Terstond treft ons een fraaie groep van den Awarrapalm (Astrocaryum aculeatum $)$ met zijn doornigen stam en rijke kroon van gevinde bladen, beladen met zware trossen zijner gele vruchten, waarvan de steel uit de betrekkelijk kleine gedorende bloeischede te voorschijn komt.

Zijn scherpe platte zwarte dorens worden als naalden gebezigd, en het schijnen dezelfde te zijn, die wij later, op Prospérité, de getrouwde 
vrouwen van een Indianenstam, die daar juist in de buurt was, in de bovenlip zagen dragen.

Onder de heesters vonden wij er van verschillende familiën : Myrtaceën (Eugenia), Melastomaceën met hun voor en achter verschillend gekleurde bladen en boogvormige aderen (Miconia holosericea), een hooge heesterachtige Hypericinée, met kleine gele bloemen (Vismia cayennensis) en kleverige bessen, die als vogellijm worden gebezigd. Voorts troffen wij een exemplaar aan van de Vochysia guyanensis, nog betrekkelijk klein (4 M.) en heesterachtig, maar reeds beladen met de gele welriekende bloemtrossen en vruchten, die gemakkelijk bereikbaar waren en dus werden medegenomen. Zij behoort tot de familie der Vochysiaceën, waarvan de verwantschap tot andere eenigzins in het duister ligt.

Ook troffen wij hier voor het eerst aan de Cachou (Anacardium occidentale), en wel met bloemen en zich ontwikkelende vruchten, zoodat wij de omvorming van den bloemsteel in de latere peervormige schijnvrucht duidelijk voor ons zagen.

Het is bekend dat de cachou, uit spleten en kerven van stain en takken, eene gom afscheidt, die als plakmiddel, even als Arabische gom, dienst kan doen, en als zoodanig reeds voor lang uit Zuid-Amerika naar Engeland werd ingevoerd. De tegenwoordig hooge prijs der Arabische gom heeft in den laatsten tijd in Nederland de aandacht op dit sur-

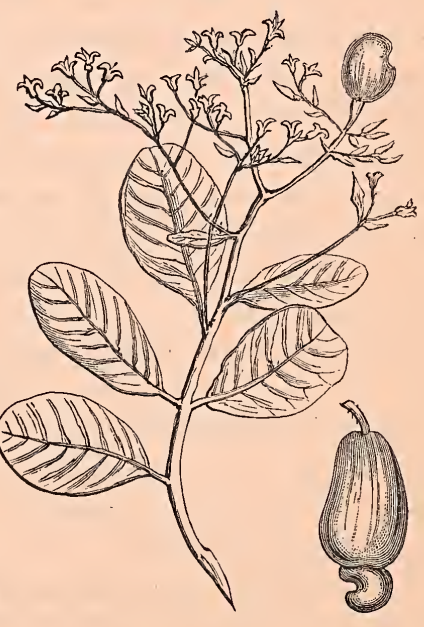
rogaat doen vestigen. Mogelijk kan dus ienand in de kolonie hiermede nog zijn voordeel doen.

Op het vasteland van Amerika wordt deze gom ook door boekbinders gebezigd, om de handen der boeken tegen mieren en andere insecten te beveiligen. Of er dan iets bijgedaan wordt van het scherpe vocht der vruchtschil, dat ook op zich zelf tot wering van insecten wordt gebruikt, is mij niet bekend geworden.

Bloeiende kruiden waren op dit oogenblik niet vele. Te vergeefs zag ik om naar Burmannia's, anders een sieraad van de Savanne. Trouwens wij hadden van deze ook maar een begin en het saisoen kan ook 
van invloed zijn geweest. Echter vond ik toch nog een Polygala, een composiet met stijve aar, Elephantopus angustifolius, kleine Malvaceën (Sida) een Gentianee met aar van gele bloemen (Coutoubea spicata), en enkele andere. Op een vochtige plaats, bij een bron door zakwater gevormd, Rhynchospora cephalotes en cyperoides, met kogelvormige hoofdjes, bij de laatste eenige tot een wijden tuil samengevoegd, en een Scirpus (retroflexus?) met kleine aartjes op haarfijne stengels, als bij onze Scirpus acicularis. Hier en daar groeide een harig vingergras, Anatherum virginicum, nabij het huis Cyperus rotundus met zijne eetbare knolletjes.

In een tuintje om en bij de woning zagen wij verwilderde tabak, een paar planten suikerriet, Amarryllis equestris als rand om een overigens geheel ledig gehouden perk, Jatropha curcas, een fraai ontwikkelde Plumiera, Citrus limonum, Ricinus communis en een groot exemplaar van Calotropis gigantea. Beide laatstgenoemde waren ook trouwe gezellen van de meer achteraf gelegen negerwoningen.

Bij Prospérité aan de Coropine-kreek, vroeger plantage, thans negerdorp, de plaats, waar wij bleven overnachten, is de vlakte eveneens open, deels grasveld, deels met heesters en verspreide boomen begroeid.

Eene wandeling langs de beek in de groene grasvlakte, op een dijkje dat deze tegen overstroomingen beschermt, aan de overzijde laag kreupelhout, deed ons zeer aan eenige deelen van Nederland denken.

Wij waren in helderen maneschijn aangekomen, na een prachtige vaart onder het van weerskanten aansluitend loofgewelf der Coropinakreek.

Vriendelijk werden wij ontvangen door den Hernhutterschen leeraar; den Heer P. Haugk en echtgenoote, die het hunne doen, en naar het schijnt met opgewektheid en toewijding, om in deze betrekkelijk afgelegen plek de zaden van beschaving en goede zeden onder de eenvoudige bevolking uit te strooien.

De gezamenlijke schoolkinderen kwamen de Gouvernante met een voor de gelegenheid geleerd lied op de wijs van „Wien Neerlandsch bloed" welkom heeten.

Met den Gouverneur en familie genoten de Heer Martin en ik de gastvrijheid in de woning Berseba van den "Lerieman" - zoo wordt de Hernhutterscher leeraar door de bevolking genoemd -, terwijl voor het verdere gezelschap op kleinen afstand gelegenheid tot logies was ingericht.

In den tamelijk grooten tuin tegenover de woning, netjes maar eenigzins stijf aangelegd, leerden wij o. a. de Pegrecoe (Xylopia salicifolia) 
kennen, eene Anonacée met kleine peperachtige vruchten en vrij stijve leerachtige bladen en regelmatig uitstaande takken, die in deze streken bij wijze van kerstboom wordt gebruikt.

Voorts was er een groote heesterachtige Loranthus, woekerende op de takken van een Erythrina.

Den volgenden morgen maakten wij eene wandeling in den omtrek naar Post Republiek (een militaire post, die weldra zal worden opgeheven) en „De vier kinderen."

De weg liep nu eens meer in de open vlakte, dan door lager en hooger hout, nu breeder, dan enger, en gaf dus van zelf aanleiding, dat het gezelschap nu eens in zijn geheel bijeen was, dan weder zich in kleinere en grootere, telkens wisselende groepjes verdeelde; hierdoor ontstond op de meest aangename wijze gelegenheid om met de verschillende leden van het gezelschap, ook die tot dusver van ons gescheiden waren geweest, nadere kennis te maken.

Somwijlen, op den breeden weg en bij de bewoonde plaatsen, waren wij omstuwd door een dansende, joelende, en groetende massa van de bevolking.

De bodem was hier alles klei en laag. Echter spreekt men ook hier van Savanne, waarmede in de kolonie elke open, niet bebouwde plaats wordt bedoeld. Slechts bij Vierkinderen was de bodem iets hooger.

Wij zagen hier o. a. de Orleans (Bixa orellana). Voorts onder de lagere heesters, in den boschrand, weder Melastomen (Miconia, waarschijnlijk longistyla), een Myrtacée (Myrcia), een Rubiacée (Palicourea crocea) met oranjekleurige bloempluimen, Heliconia's enz. Van de $P a$ licourea crocea vonden wij later de varieteit riparia bij Topibo tusschen het heestergewas bij den oever, waarlangs wij tot een heuvel, vermoedelijk verweerd dioriet, opklommen, die uit een geologisch oogpunt belang inboezemde. Daar groeiden, in een open plek, ook een paar Ipomoeasoorten en de composiet met kleine roode bloemhoofdjes, Emilia sonchifolia, als vertegenwoordigers van kruidachtigen plantengroei.

Bij onze wandeling om Prospérité zagen wij ook vrij groote uitgestrektheden, in het door licht bosch beschaduwde gedeelte van den weg, bedekt met het zoogenoemde Para-gras, Panicum molle, een uitstekend veevoeder. Ofschoon aan de oevers der Para die wij thans bezochten voorkomende, draagt het gras echter zijn naam naar Para in Brazilië, van waar het 0 . a. ook naar onze eilanden is overgebracht.

Van de vanille, die hier in het wild groeit, werd ons een vrucht aangeboden. 
In korjalen ging het weder terug naar den Triangel, terwijl onderweg onderscheidene planten van den oever werden ingezameld. Ook toen wij weder in de tentboot bij den Gouverneur waren gezeten, gaf deze met de meeste welwillendheid vergunning om nu en dan te laten stoppen, als ik takken of bloemen van de langs de kreek groeiende planten mocht verlangen. Sommigen haalde en bracht mij een vlugge neger, die ons een tijd lang in een korjaal vergezelde.

De dames namen het niet kwalijk, wanneer nu en dan de tafel vó́r ons met takken en bladen en ook met in het voorbijvaren opgevischte waterplanten was bedekt.

De Heer Benjamins wees menigen nuttigen boom aan, dien ik anders allicht bij den grooten rijkdom aan vormen, zou hebben voorbijgezien. Zijn kennis van vele inlandsche en ook verscheidene wetenschappelijke namen, bewees dat hij, bij zijn overige werkzaamheden, den lust tot natuurstudie niet verloren had. Aan hem heb ik dan ook onderscheidene namen te danken van voorwerpen, waarvan loof en bloemen te ver buiten het bereik waren om er iets van machtig te worden.

Kortom, allen werkten mede om mij te helpen. Van onderscheidene soorten werden takjes medegenomen, van andere de in het oogvallende kenmerken aangeteekend, of ruw geschetst. Op die wijze werd in de vlucht een materiaal van voorwerpen en aanteekeningen bijeengebracht, dat voor de kennis van het karakter van den plantengroei dienst kon doen.

Met behulp daarvan werd later het hier (zie pag. 36) gereproduceerde beeld ontworpen, dat uit den aard der zaak geene andere pretensie maakt dan aan de voorstelling van den Nederlandschen lezer eenigermate te gemoet te komen.

Gelijk ik reeds boven mededeelde, heeft Splitgerber destijds, in Maart I838, ook de Para bezocht, en is een verhaal van dien tocht na zijn dood, door den Hoogleeraar de Vriese uitgegeven. (Tijdschrift v. nat. Gesch. en physiologie XII. p. I63 e. v.)

Van de vegetatie langs de kreek zegt hij betrekkelijk weinig, om uitvoeriger uit te weiden over hetgeen hij in de buurt van Berlijn heeft waargenomen, zoodat mijne mededeeling de zijne kan aanvullen.

Hij eindigt met deze woorden : „Ofschoon ik later veel dieper in het binnenland doorgedrongen ben, is mij steeds de herinnering van dezen tocht alleraangenaamst gebleven. Mijne verwachting aangaande de vegetatie van Para, te voren reeds zoozeer gespannen, was nog verreweg overtroffen." 
Voor eigenlijk verzamelen was ik hier natuurlijk niet ingericht. De apparaten daartoe lagen in het ruim van de Prins Maurits. Ook zou het medenemen van volumineuse voorwerpen op dit tochtje te veel last hebben veroorzaakt.

Ik had echter een droogrekje van ijzergaas, met een pak passend droogpapier in klein formaat, voor voorkomende gevallen onder mijne bagage in de hut afzonderlijk gehouden en te Paramaribo mede aan land gebracht. Dit bewees nu, voor het doel, uitstekende diensten.

Zoo werd ongeveer een tachtigtal soorten van phanerogamen, waaronder toch ook nog enkele aanwinsten voor de flora, verzameld. Voorts al de bladmossen die ik kon verkiijgen. Ik zag er hier nergens op den bodem, maar onderscheidene op nog levende en omgevallen boomstammen.

Ik hoopte daardoor eene wenschelijke bijdrage tot de kennis van de Mosflora van Suriname, waarvan K. Müller in 1848 (Linnaea) en Dozy en Molkenboer in 1854 (Prodromus florae Bryologicae Surinamensis, Haarlem, Erven Loosjes) een begin hebben geleverd, te kunnen bijeenbrengen. Ook daarom deed ik zulks gaarne, omdat met zekerheid verwacht kon worden, dat mijn vriend Dr. C. M. van der Sande Lacoste, de laatst overgebleven bewerker van de Bryologica javanica, en die het plan van de herborisatie in onze West-Indische bezittingen van den aanvang af met warme belangstelling gevolgd had, de wetenschappelijke bewerking van dit gedeelte op zich zou willen nemen.

De Heer Benjamins verklaarde zich bereid, om op dezelfde wijze ook bladmossen te verzamelen langs de Suriname-rivier, waar hij later de Heeren Martin en van de Poll hoopte te vergezellen.

Op het oogenblik dat ik dezen schrijf (October '85) heb ik deze Musci ook reeds ontvangen, en is bij voorloopige inzage gebleken, dat de Heer Benjamins op uitstekende wijze aan zijn voornemen gevolg heeft gegeven.

Van de Phanerogamen van Suriname is veel meer bekend.

Van 1705 tot 1726 verschenen drie uitgaven van het werk van Maria Sibilla Merian over Surinaamsche insecten, maar dat tevens in de botanische litteratuur bekend is, omdat het, met de insecten, de af beeldingen der planten bevat, waarop deze leven.

Vooral echter werden bijdragen tot de kennis dezer Flora geleverd in deze eeuw, door Weigelt, Hostmann, Focke, Kegel, Kappler, Lansberge, Splitgerber, die, de een meer, de ander minder, Surinaamsche planten verzamelden. Beschrijvingen werden gepubliceerd door Miquel, Meijer, Reichenbach, Splitgerber, de Vriese.

Splitgerber, die, van Nederland uit, de kolonie bezocht en met een 
botanisch doel doorreisde, vertoefde er acht maanden, van November 1837 tot Juni 1838 .

$\mathrm{Na}$ zijne terugkomst publiceerde hij eenige stukken in het Tijdschrift voor Natuurlijke Geschiedenis en Physiologie: het overige werd na zijn dood, in $184^{2}$, aan eene hersenontsteking, gegeven door de Vriese, in het reeds genoemde Tijdschrift, in het Nederlandsch Kruidkundig Archief en in het Jaarboek van de Maatschappij voor Tuinbouw. De laatste en belangrijkste publicatie, van Miquel, zijn diens Stirpes Surinamenses selectae, een $4^{\circ}$ verhandeling van 234 bladzijden en 65 platen, in 1850 verschenen.

Het materiaal, dat tot deze beschrijvingen gediend heeft, bevindt zich voor een goed deel in de publieke herbaria te Leiden en te Utrecht.

$\mathrm{Na}$ dit materiaal en de litteratuur bestudeerd te hebben, zou een geoefend botanicus, die een langeren tijd in Suriname verblijf kon houden, en gelegenheid had, om, voorzien van de noodige hulpmiddelen tot het verzamelen en conserveeren der planten, de kolonie in verschillende richtingen te doorreizen, tot het maken van eene Flora van Suriname kunnen overgaan, en het is te hopen, dat het daartoe eenmaal komen zal.

Voor het oogenblik heeft men, naast de genoemde werken, die op de Flora van Suriname zelf betrekking hebben, de beste handleiding in het oudere werk van Aublet over Fransch Guyana, en vooral in het nieuwere van Schomburgk (Richard Schomburgk, Reizen in British Guyana 1840-1844).

In dit laatste werk zijn de plantenlijsten planten-geographisch ingericht, naar de vier hoofdsoorten van terreinen: zeekust, oorspronkelijk woud, wat hij noemt de zandsteenformatie, en de savanne.

Het spreekt van zelf, dat dit voorbeeld, met wijziging naar de lokale toestanden, ook voor Suriname zou moeten worden nagevolgd.

Voor den rijken schat van houtsoorten der kolonie zijn bijdragen geleverd door Jhr. van Sypesteyn en anderen. Eene lange lijst van I82 soorten vindt men, met de inlandsche en sommige wetenschappelijke namen in de reeds vroeger aangehaalde Catalogus der Koloniale Tentoonstelling van Amsterdam, p. 2 Io, inzending $\mathrm{N}^{\circ} .266$, van den Heer C. M. Bremer. De zeer instructieve voorwerpen, blokken, voor de helft bewerkt, voor de andere helft voorzien van den bast, maken thans deel uit van de verzameling in het Koloniaal Museum te Haarlem.

Om de wetenschappelijke namen van alle te leeren kennen, zou men de takken met bladen, bloesems en vruchten van elk er bij moeten hebben.

Wellicht zal iemand vragen : waarom heeft de inzender die niet aan zijn zoo schoone en rijke verzameling toegevoegd? Deze vraag schijnt 
zeer eenvoudig; maar wanneer men eens de tropische bosschen gezien heeft, is men tegelijk overtuigd, dat de oplossing van dit vraagstuk niet zoo eenvoudig is als de vraag zelve.

Ik kom hierop bij een latere gelegenheid nog terug, maar wil hier toch in het algemeen opmerken, dat men, de toestanden niet kennende, zeer licht onbillijk kan zijn in zijn verlangen jegens personen, die hunne eigene bezigheden hebben, en voor het verzamelen van naturalıa in veel moeilijker omstandigheden geplaatst zijn, dan wij in Europa.

Zoowel in Suriname als op de eilanden is mij voorgekomen, dat de kolonisten niet slechts gaarne hunnerzijds willen doen en bevorderen, wa tot een nauwkeuriger kennis van de kolonie strekken kan, maar dat zij zelven hoogen prijs stellen op belangstelling te dezen opzichte en op het, ook wetenschappelijk, verkeer met het moederland. Alleenlijk moet men niet alles tegelijk verlangen en, zooveel mogelijk, bepaalde vragen stellen.

Noode nam ik afscheid van deze schoone en rijke landstreek.

Des te gelukkiger waren de Heeren Martin en van de Poll in het vooruitzicht van er, na het gemeenschappelijk bezoek aan Curaçao, Aruba en Bonaire, voor eene maand te zullen terugkeeren.

Het ontbrak ook niet aan vriendelijken aandrang, om mijn reisplan in dienzelfden zin te wijzigen. Evenwel, op goede gronden had ik vooraf besloten, na het onderzoek van de eilanden onder den wind, zoo mogelijk ook de eilanden boven den wind te bezoeken.

In een maand tijds zou, bij hetgeen reeds van Suriname bekend is, wel is waar eene nieuwe bijdrage geleverd hebben kunnen worden, maar dit was van niet zoo onmiddellijk belang als een onderzoek van de eilanden, waar het veld nog ongeveer braak lag. Bovendien behooren de eilanden, wel is waar als verschillende onderdeelen, maar toch tot een zelfde plantengeographisch gebied. Een bezoek aan het vaste land van Zuid-Amerika was zeer doelmatig, omdat het gebied van den West-Indischen Archipel zich, als geheel, aan dat van Zuid-Amerika aan deze zijde van den Aequator, het naaste aansluit. Maar de eenheid in het onderzoek werd beter bewaard door een combinatie vän de eilanden boven en beneden den wind, dan van enkele van deze, en wel de vlakke en drooge benedenwindsche eilanden, met een deel van Suriname.

Ik moest dus afscheid nemen en wel voor goed, hetgeen ik evenwel niet deed zonder de aangenaamste indrukken van het verblijt in de kolonie en van de vele ondervondene vriendelijkheid en belangstelling, als blijvende herinnering, mede te nemen. 


